\title{
ABAI, THE TATARS AND THE HOUSE OF THE BEKMETOV MERCHANTS (A FEW REMARKS ON THE BOOK "ABAI: THE SEVERITY OF THE FLIGHT" BY N. A. ANASTASIEV)
}

\author{
Rinat Ferganovich Bekmetov, \\ Kazan Federal University, \\ 18 Kremlyovskaya Str., Kazan, 420008, Russian Federation, \\ bekmetov@list.ru.
}

\begin{abstract}
The article studies the biography of Abai Kunanbayev (1845-1904), more precisely, the particular aspects of its representation in the Russian publishing space. In 2008, by order of the Ministry of Culture and Information of the Republic of Kazakhstan, a new Russian systemic biography of Abai was published in the series "The Life of Remarkable People": The book "Abai: The Severity of the Flight" by the famous Russian Americanist N. Anastasyev (Moscow: "Molodaia Gvardiia", Astana: "Folio", 383 p.). This book makes a favorable impression owing to the involved historical and cultural material, its thoughtful composition and literary language. However, its event scheme and biographical outline have one notable "gap" among other ones, which is connected with the early life of the Kazakh literature classic. Nothing is said about the stay of young Abai and his father Kunanbay Uskenbaev in the Karkaraly house of the Tatar merchant Khaliulla Khamitovich Bekmetov, described in the documentary novel "The Way of Abai" by M. Auezov, which the author actively and reasonably refers to on other occasions. Meanwhile, the fact of close business and kinship-family relations between Abai's father (agha-sultan of the Karkaralinskaya volost) and Khaliulla Bekmetov deserves special attention, as it contains indirect information about the nature of Abai's rising interest in books and educational traditions. The Tatar cultural context as a whole must be taken into account in order to understand the Kazakh public consciousness of the $19^{\text {th }}$-early $20^{\text {th }}$ centuries.
\end{abstract}

Key words: Abai Kunanbayev, Kunanbay Uskenbaev, Semipalatinsk, Karkaralinsk, Tatar merchants in Kazakhstan, Khaliulla Bekmetov, Bekmetov's house.

\section{INTRODUCTION}

Back in 2008, N. Anastasyev's interesting book "Abai: The Severity of the Flight" was published in the famous series "The Life of Remarkable People" as a result of a joint project of two capital publishing houses: Moscow's "Molodaia Gvardiia" and Astana's "Foliant" [Anastasyev, 2008]. N. Anastasyev is a well-known expert in the field of Western literature in our country and abroad, he is the author of numerous beautifully thoughtful books on the works of the greatest Anglo-American writers of the $19^{\text {th }}$ and $20^{\text {th }}$ centuries (M. Twain, W. Faulkner, E. Hemingway, D. Salinger). The fictional culture of the West is the focus of his long-term research. However, despite this fact, the project customer (as indicated in the book on the back of the title page) - the Ministry of Culture and Information of the Republic of Kazakhstan - chose N. Anastasyev as the author who was given the opportunity to write a new (in fact, the first one in post-Soviet times) systemic, scientific and fictional biography of Abai Kunanbayev in Russian.
At first glance, on the surface, the choice seems to be strange: any work, large-scale in design and integral in execution, is known to be based on the sum of individual works, in this case, the work devoted to the subject of Kazakh classical literature of the late $19^{\text {th }}$-early $20^{\text {th }}$ centuries (even more precisely, the Abai theme), which are not found in N. Anastasyev's oeuvre.

At the same time, this strangeness is obviously imaginary; it is not insurmountable if we take into account several circumstances, both of substantive and organizational nature.

First, the comparative literary approach to understanding Abai does not require any special explanations and substantiations. To understand the national poet-genius in terms of the West - East cultures is both a necessary and responsible thing to do; consequently, a philologist, who has a good command of the Western material and simultaneously discovers for himself - albeit in the mode of feasible studies - Eastern context, is able to understand Abai much deeper and more subtly than the one for whom the development of literature is limited by the boundaries of one closed ethnic space 
placed in one socio-historical section. The breadth of Abai studies and the "Abai text" in Kazakh literature, therefore, should only be welcomed.

Secondly, for the customer of the project, as we assume, it was of fundamental importance how and who will be able to tell about Abai today, so that the word about him, on the one hand, would be vivid and clear; on the other hand, it should retain a share of academicism, without excessive liberty in the interpretation of the facts from his biography and worldview. In addition, the author was to be a person whose was a name to reckon with in the scientific community, who would be an authority for his readership. The fact that it was a representative of Russian not Kazakh culture who embarked upon the study of Abai's life, apparently, played the key role in this case. Thus, the idea of Abai took the form of "defamiliarization", thanks to which the familiar and well-known things (for the traditional Kazakh consciousness) revealed new and amazing features. For Kazakh culture, it is also important that a currently significant conversation about Abai (in the form of book presentations, its reviews in journals, responses and discussions by ordinary readers) is being actively conducted in Russia; I assume, this is the way the "soft power" of the spiritual and cultural values penetrates from one environment into another, from the national "outskirts", to which Kazakhstan used to belong in the pre-Soviet and Soviet periods, to the "metropolis", which, with all reservations, was Russia. N. Anastasyev is best suited for this purpose, especially since he has had a rather successful experience of working on the biographies of other Kazakh writers; he has written two books about prominent figures of Kazakhstan: one is about the modern prose writer and translator A. Nurpeisov [Anastasiev, 2004] and the other about the classic of new Kazakh literature M. Auezov [Anastasyev, 2006].

Nevertheless, the multifaceted approach to the life and creative heritage of Abai, the aim to assess him from a bird's-eye view, from the perspective of different cultures, should not negate the presence of "peripheral", "secondary" details that make up the biographical outline in its real representation; systemic work - by the very definition of this genre - presupposes taking these details into account. Meanwhile, N. Anastasyev's book has certain "lacunae" and incompleteness in the presentation of the biographical plot. These annoying "lacunae", in fact, will be discussed in the main part of this article.

\section{METHODS AND MATERIALS}

The study is based on the methodology, which, in full accordance with its logic, is made up of two traditional approaches that have stood the test of time: a) biographical and b) historical-cultural.

The first method is known to be the leading one in the humanities. In this case, its specificity is determined by the connection between the personality of the writer and his work. Certain facts from a person's life have an impact on an individual, shaping his/her spiritual and moral experience and creating conditions for the realization of latent possibilities in the depths of the soul, which are waiting for the hour to manifest themselves in one's life. The master of words is both the owner of individual ideas and inclinations and the bearer of the image of the surrounding world, the environment in which he grew up and developed.

The second method, in its turn, allows us to understand the mechanisms of personality formation from the perspective of a specific historical era and cultural traditions included in it. Here, the "near" and "distant" contexts of memory and fate are taken into account and the degree of their internal correlation is specified, due to which the description of life receives much greater reliability.

The cornerstone principles of these approaches are used depending on the material we have collected and the tasks we have set.

\section{RESULTS}

In Anastasiev's book, one of the "lacunae" concerns Abai's stay in the Semipalatinsk Tatar madrasah of Akhmet Riza, as for several years, from 1855 to 1858 , the poet mastered the canons of Islamic doctrine and oriental languages there. His studies are mentioned at length at the beginning of the second chapter "At Home, in My Yurt":

At the age of twelve ${ }^{1}$, the boy was sent to the Semipalatinsk madrasah of Imam Akhmet Riza, where he spent the next several years, memorizing the Koran suras $\langle\ldots\rangle$, learning the Arabic and Persian languages and for the first time familiarizing himself with the treasures of Oriental classical poetry, which inspired his own early timid poetic attempts [Anastasiev, 2008, p. 23].

\footnotetext{
1 An old guidebook to the Abai museum complex in Semipalatinsk says: "Abai on zhasқa tolғanda, əkesi ony Semey kalasyna əkelip madresege оқuga beredi" "When Abai was ten years old, his father brought him to Semipalatinsk and enrolled him in the Akhmet Riza madrasah" [Abai Literary Memorial Museum, p. 16, 50] (the italics are mine - R. B.).
} 
The incident of studies is also mentioned at the end of the book, which provides a simple dating of the main events in Abai's life; the black and white photograph of the Akhmet Riza mosque inside the book does not count.

However, the reader would most probably be extremely curious to find out why Kunanbay chose this very educational institution for his son, how Abai managed, while studying in a madrasah, attend a Russian parish school for a short while, and how important the Tatar element, included in the Muslim education system, was in the formation of Abai as a personality. All these questions were bypassed by N. Anastasyev - not only because in the previous Soviet era, on which the author nevertheless diligently relies, the Russophile nature of Abai's work was emphasized in every possible way, while his oriental roots were veiled, so that now, by the method of reconstruction, without having enough archival materials on hand, we have to grope our way recreating the semantic field of the poet's connections with the East, but also because (let's make an assumption) the author, for some reason, did not notice the Tatar factor when studying and setting out the history of the Steppe Territory, Semipalatinsk included, in which the Tatar merchants, with their financial and material capital, occupied an important place. The author, as you can understand, has been to this city and could have probably paid attention to the fact that the two-story house-mansion of our countryman Aniyar Moldabaev (a translator and a lawyer, an employee of a state bank), in which Abai stayed from 1878 to 1904 , a madrasah with a courtyard and a mosque - all these buildings are located in the Tatar territory of modern Semey, a unique historical place of the city, an "open-air museum". Even the minaret of the Akhmet Riza mosque here was built in the style typical of Kazan-Tatar temple architecture: by erecting it over the roof of a house.

Let's note that the Tatar Territory Complex includes other mosques that have survived to this day: a) a wooden one-minaret mosque, built with the money of the Tatar merchant I. Muzafarov in 1910 instead of the old and dilapidated one; the popular opinion that it was allegedly built by a "certain Kazakh", who wished to remain anonymous out of godly considerations, should be classified as legendary; but this, however, does not exclude feasible help in the construction of the temple rendered by the Muslim Kazakhs who traded meat and meat products nearby and called the entire district locus "bass sirak", literally "the shin of the head"; nevertheless, the mosque has always been called "Tatar" - both in terms of the general architectural and cultural-landscape design; b) a stone one-minaret mosque, created in 1908-1910 at the expense of Latyf Sadykovich Musin, the Tatar merchant of the second guild (in 1890 his father built, using European technology, the first mechanized steam mill in the city), instead of the wooden one, which was built by the Kazan Tatars back in 1837 and destroyed by fire on May 13, 1902; the architect was Abdullah Efendi, the Ottoman master (from Istanbul), helped by the self-taught Irtysh architect Bayazit Satbayev (1870-1954); a special underground passage is said to have led to the mosque from the nearby Musins' house so that the head of the family could safely visit the temple and perform namaz in any weather; c) a stone twominaret cathedral mosque, built in $1856-1862$ by the Russian architect R. A. Bolbatov (Bolotov) and the engineer-lieutenant Makashev according to Turkish design patterns on the site of a burnt-out wooden one; this construction was financed by several wealthy Tatar merchant families (the Abdyshevs, Nigmatullins, Rafikovs, Suleimenovs and Khalitovs); Abai and his father visited this mosque; its color image and description was included in the album about large Muslim temples of the Russian Empire; it was published in 1914 for the $300^{\text {th }}$ anniversary of the Romanov dynasty reign; d) a one-minaret wooden mosque on the left bank of the Irtysh, in the Zarechnaya settlement ("the city of Alash"), built thanks to the efforts of the Kazakh elder Tynybai Kaukenov, a merchant of the second guild, in 1836; the style of the mosque is defined as Siberian-Tatar. We have indicated only four mosques here; however, before the revolution, there were more of them (about 17 on the two banks of the Irtysh, according to the oral report of the local historian Shavkat Fayzullin; in the midlle 1850s, when F. M. Dostoevsky was transferred to the city as a soldier, -7 [Vrangel', p. 20]).

All this and many other things are vivid evidence of the presence and vigorous cultural activity of the Siberian and Volga Tatars in the Steppe region, which they had been exploring almost since the 1720s, when they came here, following the Cossack detachments ${ }^{2}$, to conduct commerce; it was a form of peaceful integration into the life of the Empire after a long resistance caused by the

\footnotetext{
${ }^{2}$ There were many small Tatar settlements near Semipalatinsk; one of them - the village of Akkol, founded, according to official documents, in 1812, at the beginning of the 20th century, had more than 50 houses and a mosque.
} 
fall of the Kazan Khanate in 1552. The Tatar region, located on the right bank of the Irtysh, was formed at the end of the $18^{\text {th }}$ century, after a severe flood, during which part of Polkovnichy Island, where the Tatars had settled compactly before, was flooded, and they had to move to a new territory above the area of their former residence, which they gradually made their home.

The personality of Ahmet Riza was remarkable. A Kazan Tatar, he was a disciple of Shigabutdin Mardzhani, a supporter of the Jadidism ideas (ideas of a religious reform), which penetrated the Kazakh steppe from the middle of the $19^{\text {th }}$ century. Education in the new method madrasah was more intensive in comparison with the old type madrasah; in two or three years it was possible to complete a course that took at least ten years in a Kadimist educational institution. The madrasah encouraged secular sciences, its students did not shy away from the Russian culture and language, and the mudarrises did not prevent talented students from simultaneously attending a Russian school, which Abai did not fail to take advantage of (it was once incorrectly written that he studied Russian "contrary to all the rules of the theological school" [Akhmetov, p. 61]). In the Akhmet Riza madrasah, Abai began to write his first poems in the medieval bookish Chagatai dialect, imitating the Sufi poets, from whom he traditionally drew inspiration for spiritual indulgence and patronage.

There is reason to believe that madrasah teachers developed this side of Abai's consciousness and agency, seeing it as a manifestation of his deep creative talent, since the Jadids painstakingly excluded the scholastic approach in teaching academic disciplines. Probably, Abai could have learnt a lot more if he continued his studies. However, his father needed him for practical purposes, as an administrative assistant in performing volost affairs, with their endless Steppe disputes, litigations and gossip. His son, when he became a man of respectable age with the experience of a long and difficult life, would say about it with genuine sadness in "The First Word" ("Birinshi sez"), a kind of introduction to "The Words of Edification" / "The Book of Words" ("Қara sez"):

Вұl zhasқа kelgenshe zhaқsy өtkiздik pe, zhaman өtkizdik pe, əiteuir birtalai өmirimizdi өtkizdik: alystyқ, zhұlystyқ, аitystyқ, tartystyқ - әureshilikti kөre-kөre keldik. Endi zher ortasy zhasқа kelдik; қаzhydyқ, zhlуықтуқ; қуlyp zhyrgen isimizdiң bəriniң bajansyzyn, bailausyzyn kөrdik, bəre қоrshylyқ еkeniң bildik. - I have lived either well or badly, but I have been through a lot: in struggle and quarrels, in courts and disputes, in suffering and anxiety I have reached old age, I feel exhausted, tired of everything, I have discovered the frailty and futility of my deeds, realizing the humiliation of my being [Abai, pp. 66, 186].

However, the knowledge that Abai gained in the madrasah was more than enough for him to develop to an extraordinary height after many years, in the mature period of his life. New method education was a response to the dogmatic "Mohammedan Puritanism", which Ch. Valikhanov condemned from a pro-Russian educational standpoint in his article "On Islam in the Steppe" (18631864). He called on the Russian government to limit the Tatar religious influence on the Kazakhs, interpreting it as harmful, fanatical and fruitless. "Due to the influence of the Tatar mullahs, Central Asian ishans $\langle\ldots\rangle,-$ he wrote, - our nationality $\langle\ldots\rangle$ acquires the general Muslim type $\langle\ldots\rangle$. We must bypass the Tatar period $\langle\ldots\rangle$, as since the annexation of Kazan and Astrakhan <...> [they] did not give their fatherland any well-known figure $\langle\ldots\rangle$ we must take measures to $\langle\ldots\rangle$ stop the further development of Islam $\langle\ldots\rangle$, eliminate the harmful influence of the Tatar mullahs $<\ldots>$ " [Valikhanov, pp. 293-294]. If we leave aside a much more general context (the desire of the imperial government to protect the Kazakhs from the "economic and cultural expansion of the Tatars" [Musabalina, p. 25], to weaken the "competitiveness of the Tatars in the Steppe" by administrative measures [Gibadullina, 2015, p. 124]), this attitude could have formed because by the middle of the $19^{\text {th }}$ century, Islam and all its educational institutions were experiencing a serious crisis, which was being overcome by the Jadid reforms. Abai frankly wrote about the obsolescence, sluggishness and conservatism of teaching approaches in madrasahs in "The Thirty-Eighth Word" ("Otyz segizinshi sez"):

Błl kүndegi təhsilғұlym eski medreseler głrpynda bolyp, bұl zamanғa paidasy zhoқ bolady. - Nowadays, the methods of teaching in madrasas are hopelessly outdated, they turned out to be not only useless, but also harmful [Abai, pp. 125, 243].

Let us take into account, among other things, the fact that it was the Tatar, Mullah Gabitkhan, who taught the basics of the Arab-Turkic literacy to the boy before Abai entered the madrasah; however, N. Anastasyev overlooked this fact, although M. Auezov, mentioning the ethnicity of the clergyman ("Kұnanbai қolynda Fabithan sijaқty tatardan $<\ldots>$ bolushy edi. $-<\ldots>$ he had the Tatar - Mullah Gabitkhan ... <and others - R. B.>"; 
"Gabitkhan who turned out to be a Tatar" as N. Nurtazina identified him [Nurtazina]) depicted him as a character on the pages of his novel "The Way of Abai" ("Abai zholy") in the flattering light of a keen book reader:

Fabithan da kitap окуғуsh bolatyn. Sопун kitaptarynyң ishineң өzin куzукtyrғan kөp-kөp asyl bұiymdar tapty. Mұnda Abłlқasym Tusi-Furgousi, Nizami, Fizuli, Nawai, Babyrlar bar. "Zhəmshid", "Seidbattal Fazi", "Муң bir kesh", "Tabary жаzғаn tarih", "Zhysip-Zyliқalar", "Ləili-Mәzhnynder", "Kөrұғly" sijakty hikaja dastandar da bar. Аbaidyң bas almai окуғаndary osylar [Әуезов, b. 134]. - Mulla Gabithan was a great book lover. In his collection, Abai found the works by Ferdowsi and Nizami, Fizuli and Navoi, "Jamshid" and "One Thousand and One Nights", "History" by Tabari, "Zhusup and Zuleikha", "Leili and Mezhnun", "Ker-oglu". Abai read them without stopping [Auezov, p. 146].

\section{DISCUSSION}

Another "lacuna" is connected with the fact that the author did not write a single line to describe young Abai's visit to the house of Khaliulla Bekmetov, a Tatar merchant of the second guild in Karkaralinsk, although this visit, laconically mentioned in Auezov's novel, is significant not only in terms of his everyday life:

Abai əkesimen birge Karkaralyda tłrғaly kep kynder boldy. Kazirde kys əbden tysip, қаr бекіп alғandy. Құnanbai kishkene қаlanың tap ortasyndaғy kөk shatyrly, ylken aғash yidi zhataқ etken. Қаzaғuar, қоnақshyl, tatar saudageriniң үiі [Әуезов, b. 96]. - Abai and his father had already arrived in Karkaralinsk long ago. It was winter, the snow covered the ground thickly. Kunanbay settled in the center of this small town, in a spacious wooden house with a green <lit. "blue", Kazakh 'kek' - R. B.> iron roof. The house belonged to a hospitable Tatar merchant who loved the company of Kazakhs [Auezov, p. 112].

M. Auezov did not call (did not want to call?) the "hospitable Tatar" by name, but the local historians of Karkaralinsk and the biographers of Abai know well that the book tells either about Khamit Bekmetov or about his son Khaliulla, a friend and relative of Kunanbay Uskenbaev. Let us try and summarize the scattered information about them.

The Bekmetov family, if we rely on the part of their history "documented" in Kazakhstan (their incomplete pedigree, shezhere), which is at our disposal, originates from a certain Bek Bau (according to another shezhere - Oka), who apparently lived in the middle of the $17^{\text {th }}$ century on the lands of the former Kazan Khanate. The surname
"Bekmetov" (with the Russian suffix -ov, but there are other spellings: "Bekmetev", "Bekmetyev"; the form "Bekmetev" is found in Russian sources at least from the beginning - the middle of the $18^{\text {th }}$ century; in Arabic this spelling is possibly due to the lack of the final vowels: فبيكميذ) is derived from the word "Bekmet", which, in turn, is a reduced form of the name "Muhammad" ("Ahmed", "Hamed", "Mahmud") with the addition of the lexeme "bek" ("bək") - a hereditary title of the Turkic tribal and feudal nobility. The full form was gradually lost, the shortened form became widespread, in which the lexeme "bek" was not perceived as an element indicating the social status of a person, it merged with the name: Amir / Amirkhan, Sultan / Sultanbek.

In the Tatar-Bashkir region (the Menzel and Ika rivers area) there were villages connected with the name "Bekmet": "Bekmet" / "Bekmetovo", "Dragun Bekmet", "Old Bekmet", "New Bekmet", "Saraily Bekmet"; they were founded by the Kazan Tatars, who were advancing towards the Urals, which aroused the discontent of the local Bashkirs: this is evidenced by the appeal of the Bashkir elders to the Ufa provincial chancellery on December 31, 1759. They complained that the Tatars and the "Mishars" settled on their lands "by violence, without paying rent". The text also mentions the "yasak" Tatars, Bekmetevs, - Yakup, Urazai and Musa - who lived without permit [Amirkhanov, pp. 164-165]. Among the Bashkirs, the surname "Bekmetov" is also found. So, Davletsha Bekmetov, the son of Said-Yagfar, the yurt foreman from the village of Kurmanovo in the Perm province, was a well-known person. In 1831, he traveled to St. Petersburg, having received permission to have an audience with Nicholas I: to resolve the question, painful for the Bashkirs, of the patrimonial ownership of lands.

After the fall of Kazan and the subsequent attempts to Christianize the region, a part of the clan representatives went to the southeast, to the Orenburg border area, where over time they settled in Seitovaya Sloboda (Tatarskaya Kargala), created in the middle of the $18^{\text {th }}$ century as a center of transit trade between Russia and the Middle Asia, as well as India and China ${ }^{3}$, or, in any case, they were in cooperation with the Seitian merchants, hiring out

\footnotetext{
${ }^{3}$ Seitov settlement (posad) was formed owing to the efforts of Kazan-Tatar merchants (first of all, Sagit Khayalin, who turned to the authorities of the Orenburg province with a corresponding request), who wanted to free themselves from being recruited and to freely profess the faith of their fathers, while doing business.
} 
on caravan trips. Beginning from the 1730s-1740s, the Bekmetovs were included in the category of interpreters, whose intermediary services were used by the Russian state in its relations with the vast Kazakh steppe. Thus, Aryslan Bekmetev's translation activity belongs to the abovementioned period (in Russian documents - "Araslan"; his relation to the Kazakh branch of the clan - there is a possibility of a namesake! - has been established by indirect data and needs thorough studying). This name appears in materials on the history of Bashkortostan and Kazakh-Russian relations [Sultangalieva].

Having started his career in the Ufa provincial chancellery in the 1720s (his name and surname are found in the Landrat Census of 1716-1717 as a centurion of the Arsk road in the Kazan district [Materialy landratskoi perepisi, pp. 260-261]), he served as a translator in the Orenburg border commission. He translated the letters of Abulkhair Khan (the Khan of the Junior Zhuz, or "The Lesser Kirghiz Horde", as it was written in Russian sources) to Empress Anna Ioannovna, Persian Shah Nadir and the Khan of Khiva [Sultangaliyev, p. 132] (see Aryslan Bekmetov's translations from Tatar: [Poezdka iz Orska v Khivu..., pp. 19-29], his signature is found in the land acts of the Bashkir tribes: "when writing that record, Araslan Bekmetev interpreted and certified his hand in Tatar script", here he acts as a translator of the Commission for Bashkir Affairs [see: Istoriia bashkirskikh rodov..., pp. 126-127]). He participated in difficult negotiations of the Orenburg provincial authorities with Abulkhair Khan and prepared a report on the relationships between the Bashkir and Kazakh tribes (which meant a share of political intelligence). After retiring, he settled in Seitov Sloboda and became the owner of a large courtyard with 4 mills and 25 servants of both sexes. All this was bequeathed to his three sons, one of whom, Usman Aryslanov ("Araslanov"), also served as an interpreter of the Orenburg Commission. In 1740-1741, he accompanied Dmitry Gladyshev, a lieutenant of the Orenburg dragoon regiment, during his trip to Khiva through the nomad camps of Abulkhair Khan, about which there is an entry in the "Materials of the journey of Dmitry Gladyshev, a lieutenant of the Orenburg dragoon regiment, and geodesist Ivan Muravin from Orenburg to Khiva, to visit Khan Abulkhairu (November 5, 1740-April 1741)". It is notable that in the modern scientific edition of this text, the personality of Usman Aryslanov is not commented on, it is not "recognized" [Putevye dnevniki...]. Like his father, he translated official Russian let- ters addressed to Shah Nadir, moreover, he delivered them to Persia. The following fact of his life is curious. In 1746-1747, Usman was captured by Abulkhair, becoming a hostage of the changeable relations between the Kazakh khan and the governor of Orenburg I. Neplyuev. In Kazan (according to another study - in Orenburg [Ibid], but rather, alternately in these two cities, Sultan Kozhakhmet, the son of Abulkhair, stayed from 1738 to 1748; the Russian government kept him there to ensure the khan's "pliancy". The exchange was made, and in the 1750s, Usman Aryslanov translated the official correspondence of Nuraly, the new Khan of the Junior Zhuz after the death of Abulkhair, his father (there is no information about the "technical" aspect of the exchange in the explanations to the "Materials ..."). This is by no means accidental: at that time the positions of interpreters on the border zone, according to the class-tabulation principle, "were occupied $<\ldots>$ by representatives of the titled Tatar nobility < they really did justice to themselves in the earlier period of the so-called "service Tatars", the natives of the Golden Horde. - R. B.>" [Sultangalieva, p. 127]. They were selected based on the results of a rigorous and comprehensive examination; both business qualities and state-political reliability were taken into account [Istoriia tatar, p. 339] (the latter sometimes led to mistrust on the part of the indigenous population).

As for the Kazakh branch of the Bekmetov family, it dates back to the early 1830s, when two brothers, Khamit and Jagfar Bekmetovs, arrived at the village of Po Kluchu Sap (Tat. Sap-bash / Saf (ly) bash) of the Shinshinsky volost in the Tsarevokokshai district of the Kazan province [Mustafin, 2000, p. 5], [Mustafin, 2020] . They liked the picturesque lacustrine-hilly-forest-steppe oasis of Sary Arka (the Central Kazakhstan Upland, "Kazakh Makondo", as one of today's travelers and bloggers poetically described it), business quickly took off, the brothers, first assigned to Pet-

\footnotetext{
${ }^{4}$ Now it is the village of Klyuchi-Sap in the Atninsky district of the Republic of Tatarstan, the Shor river basin, $30 \mathrm{~km}$ north of the village of Bolshaya Atnya (Oly Atnya), on the border with the Republic of Mari El. It was founded in the second half of the 18th century. In 2002, there were approximately 300 inhabitants. It is significant that according to the data of the Estimation and Statistical Bureau of the Kazan Provincial Zemstvo, 732 people of both sexes lived in it at the beginning of the 20th century (1907), all of them Tatars, despite the nearby Russian and Cheremis villages [Spisok selenii..., p. 27].
} 
ropavlovsk [Kretova, p. ... 158], got richer (especially after the opening of the Koyanda Fair in 1848, which was a trade center in the Steppe with Asian and European goods, and the opportunity to visit the border area with Xinjiang [Gibadullina, 2016, p. 34], [Gibadullina, 2017 ]). In Karkaralinsk, Khamit built a spacious two-story log house, without using a single nail, with unique Dutch stoves in each room, which Kunanbay visited as an aga-sultan (the senior sultan from 1849 to 1853) of the Karkaralinsk outer district. When, on the initiative of Kunanbay and as a result of his appeals to the higher authorities of the Russian government in 1851, the first mosque was built in Karkaralinsk (now one of the oldest in Kazakhstan, a sacral monument protected by the state); after the collective prayer, the celebration ("toi") of this event took place in the house of Khamit and Khaliullah [Mustafin, 2020], the one with a "green roof" ("Bekmetev's house under a blue roof"); Khaliulla was one of those who paid for the construction of the temple [Nurmakhanov]. The construction locus was chosen by Kunanbay, but there is information according to which he approved Khamit's proposal concerning the location of the mosque; during its construction, a company of soldiers of the Karkaralinskaya fortress was involved - under a contract, for a certain remuneration, "in their spare time" as was identified in the resolution of Major General N. Vishnevsky, the head of the Siberian border directorate [Nurmakhanov, p. 106], [Zhetpispaeva]. In the novel by M. O. Auezov, a description of the solemn post-prayer feast is given:

Kora ishindi kytushiler, aspazshylar bolmasa, өzge zhyrginshiler zhoқ <..>. Ylken ағаsh үidiң қоraға shyғатуң кең еsigine қаrsy кіshileu as үi bar edi. Sonун esigi damyl tappai ashylyp-zhabylyp zhatyr eken. Табақ-тарақ уstyқ asty <..> zhigititer zhygire basyp tasyp zhyr. Osy kire beris belmeden tөrge қаrai zhəne оң zhақ, sol zhаққа қаrai bipneshe belme bar edi. Dəl оң zhaқtағуsy Kұnanbai zhatatyn үlken belme. Sol үi zhaқtan zor dauspen kөңildene sөiler otyrғan Alshynbai, Maiyr ynderi keledi. Тұтаsқаn қаtty kүlki de estilip қоjady <..> Tөrdegi belmeler ekeu edi. Onda da zhaғalai tizilip, maldas құryp, syғуlysa otyrғan қоnақtar екен. Вұndaғy қопақту kөbi қаlanyң tatar saudagerleri, қаzақ bailary <..> kөrindi [Әуезов, b. 199-121]. - In the courtyard full of saddled horses, there was no one except servants and people busy with cooking 〈...〉. A separate kitchen was located directly opposite the porch of a large wooden house. Its door banged every now and then. Zhigits $<\ldots>$ one after another brought out dishes with hot, steaming meat $\langle\ldots>$. To the right was a large room where Kunanbay was sit- ting. From there came a loud, lively conversation $\langle\ldots\rangle$. The room opposite the entrance was also packed with guests sitting in a tight circle. These were mainly urban merchants - the Tatars and Kazakh bays [Auezov, pp. 133-134].

The mosque combined Kazakh and Tatar architectural and decorative elements. The first imam of the mosque, at the invitation of Kunanbay, was Akhun Khasan Seifullin, a "Kazan Tatar" according to archival records, a Meshcheryak from Saratov; he died in 1881 in Jeddah during the plague, performing the hajj (Magzum, the daughter of the akhun, was the wife of Gubaidulla, the son of Jagfar Bekmetov, they had seven children; Gubaidulla was the imam of the mosque after the death of Hasan). The father of Khamit and Djagfar Bekmetovs was Yakhya (in Russian government papers they are both named "Yakhnins" by their patronymic names). According to some sources, Khamit was born in 1808 [Mustafin, 2020], according to others, in 1811 [Omirdiң bel-belesteri, p. 195]. He had 20 children by four wives (their names are recorded in a special "extract from the last list of family members of the deceased merchant Khamit Bekmetev", compiled in the Karkarali district chancellery); his younger brother had three children.

Khaliullah was Khamit's firstborn: in the "Extract ..." he is the oldest. The dates of his birth vary: either 1829 or 1833 , and the date of death is May 6, 1905 (nothing is known about the year of his father's death; it is assumed that Khamit returned to his homeland). His mother was Sahipdzhamal, who is considered to be a Kazakh (perhaps not entirely pureblooded). Besides Khaliullah, she had two sons: Hamidullah and Gizzatullah. One of Khamidulla's sons, that is, the grandson of Khamit and the nephew of Khaliullah, Mohammed-Maksud Bekmetov (1883-1912), a friend of A. B. Baitursunov and A. N. Bukeikhanov, prominent representatives of the Kazakh intellectuals, was an employee of the Omsk telegraph and post office, he participated in the general strike of Russian postal workers in 1906 and collected Kazakh national folklore (see about him: [Abdrashitov, Uzbakhanov], see the anthology of Kazakh poems (steppe melodies) compiled by him and published in Kazan [Bekmetev]). Khaliullah not only traded, like his father (flour, bread, groceries, manufactory, etc.), but was also engaged in charity work. As the public chairman of the Karkaraly Prison Guardianship Department, he donated money to improve the life of prisoners, in connection with which the military governor of the 
Semipalatinsk region twice expressed his "sincere and heartfelt gratitude" in the orders of April 23, 1885 and September 15, 1892. Moreover, on October 12, 1888, Emperor Alexander III awarded the merchant with a silver lapel medal with the inscription "For Diligence" on the Stanislavskaya ribbon, and in December 1904, Tsar Nicholas II presented him with the gold medal "For Diligence" on the Anninskaya ribbon to be worn around the neck [Zhamuldinov, pp. 42-43], [Popov, p. 6].

In Karkaralinsk, subscription lists were distributed with the aim of raising funds to help orphans, old people, military invalids and ordinary people who found themselves without financial support (often after fires, when whole neighborhoods of wooden buildings burned out). Khaliullah and his relatives always contributed significant sums to these sheets; so, the subscription list of 1911 was preserved in the amount of 72 rubles. 15 kopecks: among the signatories - Makhmud and Maksut Bekmetov [Popov, Riazantsev, p. 107]. Khaliulla was among those patrons of art who financed the construction of the St. Petersburg Cathedral Mosque (his name in Arabic is inscribed on one of the walls of the temple) [Kereybaeva, p. 145].

In 1905, along with other, mostly Russian, merchants, Khaliullah was a member of the Karkarali Society of Popular Sobriety ${ }^{5}$.

\footnotetext{
${ }^{5}$ These noble activities did not interfere with sometimes "wasting" money! In Soviet times, old residents of Karkarlinsk said that the Bekmetov merchants used to heat samovars with banknotes. This happened, for example, during the matchmaking of their daughters to find out the size of the wallets of their fiance's, and to clarify the degree of their efficiency, suitability for life, and the seriousness of their attitudes to the choice of their beloved ones. Such humorous stories were told, of course, to amuse visitors of Karkaralinsk, tourists interested in local customs. But just as there is no smoke without fire, so numerous and funny stories about merchants cannot be spread without specific events, recorded almost "documentarily". The fact is that the burning of banknotes to heat a samovar is an almost invariant plot, it is persistently repeated in different versions. This is not just an old trivial joke dating back to Soviet times and told with the aim of showing how differently people used to live before the revolution, and how they live now, under the new government - "heaven and earth". No, the story of money and a samovar was common in the $19^{\text {th }}$ century, when at the Kuyandinsky fair, the Bekmetov and Ryazantsov merchants, in the heat of trade competition, argued who would be able to quickly prepare evening tea by burning banknotes in the samovar. The Tatar merchants were said to have won: they had to use cash intended to purchase a coal mine, which the next morning after the heated "debate" went into the
}

Khaliullah and his family members owned mountain mines, the Steppe region was rich in them. According to the imperial law, ore mining at one and the same place was to be carried out for three years, after which the mine was declared free, and its temporary owner had to send a new application to the Tomsk mining district to continue the work. "The Siberian Commercial and Industrial Calendar", issued in Tomsk, published a list of persons licensed to develop mines. According to Yu. Popov's estimates, about 100 applications (!) were filed from the Bekmetov family at different times [Popov, p. 6]. Many mines of the Balkhash region were designated by the names of the Bekmetovs' house members: Asatovsky, KhakimMaksutovsky, Muginovsky, MakhmudMukhtarovsky, Dildanovsky, Khamitovsky, Gulshadsky (in honor of Khaliulla's niece, Gulshad, who was the daughter of his brother Khamidulla; at the beginning of the 1950s this mine was described as follows: "In Gulshad, mimetesite <a rare mineral from the class of phosphates. - R. B.> is most common in the area of the Bekmetev spacing... In the steppe part of Kazakhstan, scorodite <a poisonous mineral used to extract arsenic. - R. B.> in substantial quantities is only found in the Gulshat deposit ..." [Chukhrov, p. 145]; in 1885, near this ore mine, a plant was built, at which silver was extracted by an experimental method in reverberatory furnaces [Pazukhin, p. 42]); the name of the metallurgical plant on the shore of Lake Balkhash was PopovoBekmetovsky (owned jointly with the merchant Stepan Popov).

Khaliullah had four wives: 1) Latifa, the daughter of Iskhak, 2) Khadicha, the daughter of Rafik, 3) Fatima, the daughter of Musa, 4) Gaini (1846-1927). There were no children by the first

hands of more enterprising and less adventurous Englishmen. Moreover, F. M. Dostoevsky, who was in exile in Semipalatinsk (served as an ordinary soldier of the Siberian line battalion) at that time, could have heard this or a similar piece of "gossip", a ridiculous argument in favor of the strange customs of the Steppe - the distant imperial periphery. I recall the episode of the night binge, depicted in the novel "The Idiot": Nastasya Filippovna takes packs of money from merchant Rogozhin in her St. Petersburg apartment and throws them into the oven, setting the condition that if someone should manage to get at least a pack out of the fire, he would receive all hundred thousand. In any case, the described fact with a samovar needs detailed historical and cultural coverage, starting with the question of whether it really happened or not, and ending with the semiotics of merchant gestures and actions. 
two wives; the third gave birth to three (one daughter and two sons); the fourth had five (one daughter and four sons). The last wife, Gaini, (or, as the Kazakhs affectionately called her, Aineke) was the daughter of Shonbai from the clan of Tobykta, a close relative of Kunanbay. She became a widow early (her husband Smail <Ismagil. - R. B. > died after falling from a horse), in her first marriage she had two young children [Bekmet'eva, p. 125]. Kunanbai, who visited Khamit's house, suggested that Khaliullah should marry young Gaini and adopt her children. He agreed - not only out of a desire to be related to Kunanbay, but also because he had had no children by his first three wives by the time of the next matchmaking. When Gaini came to live in his house, Fatima, who was Uzbek and was thought to be sterile, began giving birth ... It was Gaini who was associated with the cult of children and childhood. According to the memoirs of her contemporaries, outwardly stern, at heart she was the kindest person. The fate of Gaini's children by Smail was tragic: Zhakypbek fell victim to political repression in the 1930s, Rabiga died in obscurity in $1951^{6}$. At the same time, Khaliullah's other children, including those by Gaini, made a great contribution to the development of Kazakh and Russian! - culture (he had eight children by his two wives: one daughter and two sons by Fatima, and four sons and one daughter by Gaini). All of them, their relatives and descendants got a good education: suffice it to say that Khaliullah's daughter by Fatima, Gulbahor, married Zhakyp Akpayev (1876-1934), the first Kazakh master of law, who graduated from the law faculty of the Imperial St. Petersburg University, an ethnographer, a public leader and a member of the "Alash-Orda" government, which advocated the European, Western path of the nation's development and was abolished by the Bolsheviks; Makhfuza (188? -1956), the daughter of Gubaydulla Bekmetov, Khaliullah's cousin, was officially married to Amre Aitbakin (1861-1919), the first Kazakh professional doctor,

\footnotetext{
6 Khamit had a son, Khakimzhan, by Khusni (Khusnidzhamal), his second wife after Sahipjamal. He was Khaliullah's half-brother, lived in his family, being, as it were, "adopted", as he was the right age: all because Khaliullah's did not have his own children for a long time. Khakimzhan, Khaliullah's favorite (a blackand-white photograph has come down to this day, in which there are both of them: "a brother-father" gently holds "his brother-son" by the shoulder), died after completing a course at the Siberian Cadet Corps in Omsk, the best military educational institution in prerevolutionary Russia.
}

the leader of the political party "Alash" [Fominykh, Kuzmin, Nekrylov], his sister was the wife of Zeynep Chormanova's nephew, the mother of Chokan Valikhanov; Khaliullah's granddaughter, the daughter of his son Mazhit, Gulgasyl, was married to Anatoly Stepanovich Ivanov (19281999), the author of the popular novels "Shadows Disappear at Noon", "The Eternal Call" and the story "Ermak", the editor of the journal "The Young Guard" (for her husband Gulgasyl Mazhitovna Bekmetova meant nearly as much as Sofya Andreevna Bers meant for Lev Nikolaevich Tolstoy: it is not accidental that the text of the novel "Shadows Disappear at Noon" was dedicated to his wife - "Galina Ivanova, my faithful friend") ${ }^{7}$.

Khaliullah used to visit St. Petersburg on business. Naturally, from there he brought books in Russian, which replenished his home library, represented by Arab, Persian and Turkic-Tatar editions. We can assume that the inquisitive Abai also used it. Music could be heard in the Bekmetovs' house: one of the young people played an instru-

\footnotetext{
${ }^{7}$ Of interest are D. Bykov's statements about the place of A. Ivanov's prose in Soviet and post-Soviet literature. They are worth mentioning. Paying tribute to the talent of the writer ("Ivanov had an undoubted gift of a novelist"), D. Bykov called him a "genius for the poor" and underlined that this was not bad at all ("processing high samples for an average reader is an absolutely noble task"). The chronicle of the era, from his point of view, was not only the novels of M. Sholokhov, but also the works of A. Ivanov. As a conclusion: "When we start $<\ldots>$ to build a normal national identity $\langle\ldots\rangle$, we will have to reread his $<$ A. Ivanov's. - R. B.. $>$ prose. Adapting great models for unprepared readers, $<\ldots>$, supplying them with information about historical past and modernity is one of the tasks of literature. $\langle\ldots>$. And those who grew up on $\langle\ldots\rangle$ Ivanov $-<\ldots>$ provided the country with a margin of safety, thanks to which it did not collapse after the next revolution. <...> If today there was a person who would not be afraid to become a genius for the poor, the country would have noticeably fewer poor people < poor intellectually, spiritually, morally. - R. B.>" [Bykov, pp. 411-412]. It should be noted that the circulations of A. Ivanov's works are still high, and readers' reviews of his works, even on the Internet, are invariably positive; they reflect not only people's nostalgia for a bygone era, but also a sense of what genuine mass literature should be: easy to read, deep in thought, leaving a subtle pleasant aesthetic "aftertaste". Many people write that the writer remained underestimated, and this is true: "The Life of Remarkable People" has not published his biography! Soviet film serials, based on the novels of A. Ivanov (original author's script, acting, musical design, color scheme, entourage, Siberian nature), also evoke constant enthusiasm.
} 
ment (violin, accordion), and the parents encouraged their children's talents (by the way, it was a custom for the children in the family to have "internal", home names). As a result, the cultural environment could not but influence the young Abai; he breathed the air of knowledge and freedom in the generous Bekmetov's house.

Khaliulla Khamitovich Bekmetov was buried in the ancestral part of the Karkaraly cemetery. The stone on his grave was brought from India, the iron fence was made by the local craftsman, blacksmith Kynabay [Mustafin, 2016].

\section{CONCLUSIONS}

The fact of Kunanbay's warm meetings with the Bekmetovs could have been mentioned in the book - briefly, in concise, ascertaining wording, without departing from the main trajectory of the narrative. Athough, to be fair, it should be said that $\mathrm{N}$. Anastasyev stipulates the genre boundaries of his work. In the "Prologue", he writes that his book is neither a biography, nor a literary-critical essay, but a portrait, a sketch, or - in a more lyrical refraction - "a medallion in a fluctuating environment of invited or called participants in the literary and social life of previous centuries" [Anastasiev, 2008, p. 7]. This remark is essential: it corresponds to the author's logic in comprehending Abai's work (and not only his: any artist's!). We do not aim to dispute or revise it, realizing that without inner spiritual intimacy (N. Anastasyev explains that he does not have it for objective reasons), it is really difficult to describe a biography. We point to the background ("environment") of Abai's early sociocultural life, the background, which nevertheless lay on the surface and, due to a too generalized approach to the topic, remained completely unnoticed. An almost the same situation is true of $\mathrm{O}$. Ibraimov's book about Ch. Aitmatov, published in the same series "The Life of Remarkable People" ten years later [Ibraimov]. True, the Tatar origins of the Kyrgyz writer on the side of his mother (now it is impossible to silence this fact!) are mentioned - but, alas, sparingly, on one or two pages, without involving a huge amount of material about the glorious merchant family of the Abduvalievs.

\section{References}

Abai (2001). Kara sez [The Book of Words]. 264 p. Semei, Mezhdunarodnyi klub Abaia. (In Kazah)

Abdrashitov, Kh., Uzbakhanov, N. (1987). V god velikogo probuzhdeniia [In the Year of the Great Awakening]. 104 p. Alma-Ata, Zhalyn. (In Russian)

Amirkhanov, R. Kh. (2010). Rodoslovnaia Amirkhanovykh [The Amirkhanovs' Pedigree].
Tatarskie murzy i dvoriane: istoriia i sovremennost': materialy Vserossiiskoi nauchno-prakticheskoi konferentsii, g. Kazan', 9 aprelia 2010 goda. Vyp. I, pp. 156-247. Kazan', izd-vo "Fon” AN RT. (In Russian)

Anastas'ev, N. A. (2004). "Nebo v chashechke tsvetka": Abdizhamil Nurpeisov i ego knigi v miro-vom literaturnom peizazhe ["The Sky in a Flower Cup": Abdizhamil Nurpeisov and His Books in the World Literary Landscape]. 303 p. Almaty, Olke. (In Russian)

Anastas'ev, N. A. (2008). Abai: tiazhest' poleta [Abai: The Severity of the Flight]. 383 p. Moscow, Molodaia gvardiia, Astana, Foliant.

Anastas'ev, N. A. (2006). Mukhtar Auezov: tragediia triumfatora [Mukhtar Auezov: The Tragedy of a Triumphant]. 449 p. Moscow, Molodaia gvardiia. (In Russian)

Auezov, M. (1971). Put' Abaia: roman-epopeia v 2 tomakh [Abai's Path: An Epic Novel in 2 Volumes]. Per. s kazakhsk. T. I, 715 p. Moscow, Khudozhestvennaia literatura. (In Russian)

Akhmetov Z. A. (1949). Pushkin i Abai [Pushkin i Abai]. Vestnik Leningradskogo universiteta. No. 6. pp. 60-70. (In Russian)

Baskakov, N. A. (1979). Russkie familii tiurkskogo proiskhozhdeniia [Russian Surnames of Turkic Origin]. 280 p. Moscow, Nauka. Glavnaia redaktsiia vostochnoi literatury. (In Russian)

Bekmetev, M.-M. Kh. (1908). Қаzақ өley̧deri: қаzақ̆tyң zhaқssy өleң̧derdiң zhyeldy [Kazakh Poems: A Collection of Good Kazakh Poems]. 18 p. Kazan, Matbuga Korimiia. (In Kazakh)

Bekmet'eva, Zh. (2000). O dome s zelenoi kryshei [About the House with a Green Roof]. Prostor. No. 12, pp. 123-130. (In Russian)

Bykov, D. L. (2013). Sovetskaia literature: kratkii kurs [Soviet Literature: A Brief Course]. 416 p. Moscow, PROZAIK. (In Russian)

Chukhrov, F. V. (1951). Mimetezit i skorodit $v$ stepnoi chasti Kazakhstana [Mimetesite and Scorodite in the Steppe Part of Kazakhstan]. Trudy Mineralogiche-skogo muzeia. Vyp. 3, pp. 144-146. Moscow, izd-vo AN SSSR. (In Russian)

Fominykh S. F., Kuz'min, A. N., Nekrylov, S. A. (2011). Amre Aitbakin - vospitannik Imperatorskogo Tomskogo universiteta, pervyi diplomirovannyi kazakhskii vrach [Amre Aytbakin - a Graduate of the Imperial Tomsk University, the First Certified Kazakh Doctor]. Sibirskii zhurnal klinicheskoi i eksperimental'noi meditsyny. T. 26. No. 1. Vyp. 1, pp. 177-180. (In Russian)

Gibadullina, E. M. (2015). Pravovye aspekty uchastiia tatar $v$ torgovo-promyshlennoi deiatel'no-sti na territorii Kazakhstana vo II polovine XIX - nachale $X X$ vekov [Legal Aspects of the Tatars' Participation in Commercial and Industrial Activities on the Territory of Kazakhstan in the Second Half of the $19^{\text {th }}-$ Early $20^{\text {th }}$ Centuries]. Dukhovnaia zhizn' rossiiskikh regional'nykh soobshchestv: istoriia, traditsii, sovremennost': sbornik statei IV Mezhdunarodnoi nauchnoi konferentsii, g. 
Kazan', 20-21 oktiabria 2015 goda. pp. 122-126. Kazan', izd-vo KGASU. (In Russian)

Gibadullina, E. M. (2016). Tatary Semipalatinska v torgovle s Kitaem vo II polovine XIX - nachale XX vekov [Semipalatinsk Tatars Trading with China in the Second Half of the $19^{\text {th }}-$ Early $20^{\text {th }}$ Centuries]. Noveishie dostizheniia $\mathrm{v}$ nauke i obrazovanii: sbornik nauchnykh trudov po materialam Mezhdunarodnoi konferentsii, g. Smolensk, 31 avgusta 2016 goda. Smolensk, OOO "Novalensko", pp. 32-34. (In Russian)

Gibadullina, E. M. (2017). Uchastie tatar $v$ periodicheskoi torgovle Kazakhstana. XVIII - nachalo $X X v v$. [The Participation of the Tatars in the Periodic Trade of Kazakhstan. The $18^{\text {th }}$-Early $20^{\text {th }}$ Centuries]. 384 p. Kazan', RITs “Shkola”. (In Russian)

Ibraimov, O. I. (2018). Chingiz Aitmatov [Chingiz Aitmatov]. 221 p. Moscow, Molodaia gvardiia. (In Russian)

Istoriia bashkirskikh rodov (2014) [The History of Bashkir Clans]. Enei. T. I. 432 p. Ufa, Ufimskii poligrafkombinat. (In Russian)

Istoriia tatar: $v 7$ tomakh (2013) [The History of the Tatars: In 7 Vol.]. T. VI. 1172 p. Kazan', izd-vo AN RT. (In Russian)

Kereibaeva, A. S. (2016). Blagotvoritel'naia $i$ metsenatskaia deiatel'nost' predprinimatelei Stepnogo kraia II poloviny XIX - nachala XX vekov v kontekste rossiiskoi gosudarstven-noi politiki: istoriograficheskii aspect [Charitable and Philanthropic Activities of Entrepreneurs from the Steppe Territory in the Second Half of the $19^{\text {th }}-$ Early $20^{\text {th }}$ Centuries in the Context of Russian State Policy: A Historiographic Aspect]. Kazakhi Evrazii: istoriia i kul'tura. pp. 143-150. Omsk, izd-vo OmGU, Pavlodar, izd-vo PGPU. (In Russian)

Kretova, T. (2019). Po sakral'nym mestam Vostochnogo Kazakhstana [Sacred Places of East Kazakhstan]. Prostor. No. 4, pp. 154-164. (In Russian)

Literaturno-memorial'nyi muzei Abaia: pamiatka dlia posetitelei (1960) [Literary Memorial Museum of Abai: A Memo for Visitors]. Sost. G. Mukhametkhanov, M. I. Shatalin. 70 p. Semipalatinsk, Glavizdat Ministerstva kul'tury KazSSR. (In Russian)

Materialy landratskoi perepisi 1716-1717 godov (2018) [Materials of the Landrat Census of 1716-1717]. Kazanskii uezd. Rodnoi krai (Tugan жir). No. 1, pp. 256-261. (In Russian)

Musabalina, G. T. (2010). Obshchestvennopoliticheskaia zhizn' Vostochnogo Kazakhstana v XIX veke: istoricheskii analiz: avtoref. dis. ... dokt. istor. nauk [Social and Political Life of East Kazakhstan in the $19^{\text {th }}$ Century: Historical Analysis: Doctoral Thesis Abstract]. Almaty, izd-vo "Tengri”, 40 p. (In Russian)

Mustafin, E. (2020). Karkaralinskoe okruzhenie Kunanbaia [Karkarali Environment of Kunanbay]. Kazakhstanskaia pravda. 24 sentiabria. URL: https://www.kazpravda.kz/articles/view/karkaralinskoeokruzhenie-kunanbaya (accessed: 30.12.2020). (In Russian)

Mustafin, E. (2016). O chem molchat pamiatniki [What the Monuments Keep Silent about].
Kazakhstanskaia pravda. 1 oktiabria. URL: http://www.inkaraganda.kz/articles/142555 (accessed: 15.01.2021). (In Russian)

Mustafin, E. (2000). Tatarin, liubivshii obshchestvo kazakhov [A Tatar Who Loved the Company of Kazakhs]. 2 noiabria. 10 p. Karaganda. (In Russian)

Nurmakhanov, A. K. (2017). Mechet' Kunanbaia Khadzhi $v$ Karkaraly [Kunanbai Haji Mosque in Karkaraly]. (Po materialam polevykh issledovanii) Kazakhstan v XXI veke: v tsentre vnimaniia: materialy VI Mezhdunarodnoi nauchno-prakticheskii internetkonferentsii, posviashchennoi vystavke "EXPO-2017" v Astane. pp. 105-108. Astana, izd-vo ENU imeni L. N. Gumileva. (In Russian)

Nurtazina, N. D. Abai i islam. Alma-mater Ibragima Kunanbaiuly - medrese Akhmet-Riza [Abai and Islam. Ibrahim Kunanbayuly's Alma-mater - Ahmet-Riza Madrasah]. URL: https://www.altyn-orda.kz (accessed: 20.12.2020). (In Russian)

Pazukhin, V. A. (1926). Metallurgiia v Kirgizskoi stepi [Metallurgy in the Kyrgyz Steppe]. 208 p. Moscow, Leningrad, Promizdat. (In Russian)

Poezdka iz Orska v Khivu i obratno, sovershennaia v 1740-1741 godakh Gladyshevym i Mu-ravinym (1851) [A Trip from Orsk to Khiva and Back, Made in 17401741 by Gladyshev and Muravin]. Izd. S priobshcheniem sovremennoi karty Millerova puti ot Orska do Ziungorskikh vladenii i obratno, Ia. V. Khanykovym, deistvitel'nym chlenom Imperatorskogo Russkogo geograficheskogo obshchestva. 85 p. St. Petersburg. (In Russian)

Popov, Iu., R'azantsev, V. P. (2012). Kornilovy, Karbyshevy, R'azantsevy $i$ drugie kazaki stanitsy Karkaralinskoi (shtrikhi kraevedcheskoi letopisi) [The Kornilovs, Karbyshevs, Ryazantsevs and Other Cossacks of Karkaralinskaya Village of (Extracts from the Local History Chronicle)]. 142 p. Novosibirsk, ARTA. (In Russian)

Popov, Iu. (2007). Privez kupets "ogon' sviashchennyi"... [The Merchant Brought the "Sacred Fire" ...]. Kazakhstanskaia pravda. 4 avgusta. 12 p. (In Russian)

Putevye dnevniki $i$ sluzhebnye zapiski o poezdkakh po iuzhnym stepiam. XVIII-XIX vv. (2007) [Travel Diaries and Service Notes on Trips to the Southern Steppes. The18th-19th Centuries].Istoriia Kazakhstana po russkim istochnikam XVI-XX vv. T. VI. Almaty, Daikpress, URL: http://www.vostlit.info/Texts/Dokumenty/ M.Asien/XVIII/17401760/Muravin_2/text1.htm (accessed: 26.12.2020). (In Russian)

Spisok selenii Kazanskoi gubernii (1913) [The List of Villages in the Kazan Province]. Vyp. 11. Tsarevokokshaiskii uezd. 43 p. Kazan', Lito-Tipografiia I. N. Kharitonova. (In Russian)

Sultangalieva, G. S. (2009). Deiatel'nost' tatarskikh perevodchikov, tolmachei Orenburgskoi pogranichnoi komissii v Kazakhskoi stepi (XVIII-XIX vv.) [Tatar Translators' Activities, Interpreters of the Orenburg Border Commission in the Kazakh Steppe (the $18^{\text {th }}-19^{\text {th }}$ 
Centuries)]. Nauchnyi Tatarstan. No. 4, pp. 125-138. (In Russian)

Valikhanov, Ch. (1986). Izbrannye proizvedeniia [Selected Works]. 414 p. Moscow, Nauka, Glavnaia redaktsiia vostochnoi literatury. (In Russian)

Vrangel', A. E. (1812). Vospominanija o F.M. Dostoevskov v Sibiri 1854-1856 gg. [Memories about F. M. Dostoevsky in Siberia 1854-1856]. 221 p. SaintPeterburg, Tipografiia A. S. Suvorina. (In Russian)

Zhamuldinov, V. N. (2013). Stanovlenie i razvitie v Kazakhstane instituta obshchestvenogo vozdeistviia na osuzhdennykh, ego sovremennoe sostoianie $i$ perspektivy [Formation and Development of the Institution of Social Action towards Convicts, Its Current State and Prospects in Kazakhstan]. Vestnik Permskogo instituta FSIN Rossii. No. 1(8), pp. 39-45. (In Russian)
Zhetpispaeva, A. (2020). Skvoz' veka i zabvenie [Through the Centuries and Oblivion]. Industrial'naia Karaganda. 13 iiunia. http://www.inkaraganda.kz/ articles/158066 (accessed: 08.01.2021). (In Kazakh)

Ouezov, M. (2004). Abai zholy: roman-epopeia, birinshi kitap [Abai's Way: An Epic Novel, the First Book]. 366 p. Almaty, Zhazushy. (In Kazakh)

Omirdiy bel-belesteri. Peripetii sud'by: posviashchaetsia 90-letnemu iubileiu Berkutbaia Aidarkhanova $i$ 85-letiiu Khalidy Bekmetevoi (2008) [Circles of Life. The Twists and Turns of Fate: Dedicated to the 90th Anniversary of Berkutbay Aidarkhanov and the 85th anniversary of Khalida Bekmeteva]. 249 p. Almaty. (In Kazakh)

\title{
АБАЙ, ТАТАРЫ И ДОМ КУПЦОВ БЕКМЕТОВЫХ (НЕСКОЛЬКО ЗАМЕЧАНИЙ К КНИГЕ Н. А. АНАСТАСЬЕВА «АБАЙ: ТЯЖЕСТЬ ПОЛЕТА»)
}

\author{
Ринат Ферганович Бекметов, \\ Казанский федеральный университет, \\ Россия, 420008, г. Казань, ул. Кремлевская, д. 18, \\ bekmetov@list.ru.
}

\begin{abstract}
Статья посвящена проблеме изучения биографии Абая Кунанбаева (1845-1904), точнее частным аспектам ее изложения в российском книгоиздательском пространстве. В 2008 году в серии «Жизнь замечательных людей» по заказу Министерства культуры и информации Республики Казахстан вышло в свет новое русское системное жизнеописание Абая - книга известного отечественного американиста Н. А. Анастасьева «Абай: тяжесть полета» (М.: «Молодая гвардия», Астана: Фолиант, 383 с.). Книга эта по набору привлеченного историкокультурного материала, композиционной продуманности, литературному языку производит благоприятное впечатление. Вместе с тем в событийной схеме, биографической канве книги имеется в числе прочих одна заметная «лакуна», которая связана с ранним этапом жизни классика казахской литературы. Ничего не сказано о пребывании молодого Абая вместе с отцом Кунанбаем Ускенбаевым в каркаралинском доме татарского купца Халиуллы Хамитовича Бекметова, о чем, между прочим, пишется в документальном романе М. О. Ауэзова «Путь Абая», на которого автор - по другим поводам - активно и обоснованно ссылается. Между тем факт тесных деловых и родственно-семейственных отношений отца Абая (ага-султана Каркаралинской волости) с Халиуллой Бекметовым заслуживает особого внимания, ибо содержит косвенную информацию о характере пробуждения интереса Абая к книге и просветительской традиции. Татарский культурный контекст в целом необходимо учитывать для понимания казахского общественного сознания XIX - начала XX века.
\end{abstract}

Ключевые слова: Абай Кунанбаев, Кунанбай Ускенбаев, Семипалатинск, Каркаралинск, татарское купечество в Казахстане, Халиулла Бекметов, дом Бекметовых.

\section{1. Введение}

В уже далеком 2008 году в знаменитой серии «Жизнь замечательных людей» была опубликована небезынтересная книга Н. А. Анастасьева «Абай: тяжесть полета» - результат совместного проекта двух столичных издательств: московской «Молодой гвардии» и ас- танинского «Фолианта» [Анастасьев, 2008]. Н. А. Анастасьев - известный в нашей стране и за ее пределами специалист в области западной литературы, автор многочисленных прекрасновдумчивых работ по творчеству крупнейших англо-американских писателей XIX и XX столетий (М. Твена, У. Фолкнера, Э. Хемингуэя, Д. 
Сэлинджера). Художественная культура Запада - объект его долголетнего исследовательского внимания. Однако, несмотря на это, заказчик проекта (так обозначено в книге на обороте титульного листа) - Министерство культуры и информации Республики Казахстан - выбрал именно Н. А. Анастасьева в качестве того автоpa, которому была предоставлена возможность написать новую (по сути, первую в постсоветское время) системную научно-художественную биографию Абая Кунанбаева на русском языке.

На первый, весьма поверхностный взгляд, выбор достаточно странный: известно, что всякий масштабный по замыслу и целостный по исполнению труд складывается как минимум из суммы отдельных частных работ, а как раз их по тематике казахской классической литературы конца XIX - начала XX века (еще точнее, абаевской тематике) у Н. А. Анастасьева нет. Вместе с тем странность эта носит очевидномнимый характер; она вполне преодолима, если учесть несколько обстоятельств как содержательного, так и организационного плана.

Во-первых, сравнительно-литературоведческий (компаративный) подход в осмыслении Абая не требует особых пояснений и обоснований. Понять национального поэта-гения в координатах культур Запада и Востока - дело и необходимое, и ответственное, так что филолог, хорошо владеющий западным материалом и одновременно открывающий для себя - пусть в режиме посильных штудий - восточный контекст, способен увидеть Абая значительно глубже и тоньше, нежели тот, для кого развитие литературы ограничивается пределами одного замкнутого этнического пространства, помещенного в один социально-исторический срез. Широта изучения Абая и «абаевского текста» казахской литературы, таким образом, должна лишь приветствоваться.

Во-вторых, для заказчика проекта, как мы предполагаем, принципиальное значение имело и то, кто и как сумеет сегодня рассказать об Абае, чтобы слово о нем получилось, с одной стороны, живым и ясным, а с другой - сохраняющим долю академизма, без излишней вольности в интерпретации фактов биографии и мировоззрения. Кроме того, автором должен был быть человек, чье имя весомо в научной среде, авторитетно для читательской аудитории. Ключевую роль, по-видимому, играл тот факт, что о жизни Абая взялся писать представитель не казахской, а русской культуры - тем самым, представление об Абае принимало форму «остранения», благодаря которой обычно в привычном и знакомом (для традиционного казахского сознания) открывается нечто новое и по-своему удивительное. Для казахской культуры важно и то, что актуально значимый разговор об Абае (в виде презентаций книги, рецензий на нее в журналах по профилю, откликах и обсуждениях рядовых читателей) стал активно вестись в России; в этом, если подумать, и проявляется действие «мягкой силы» как способа проникновения духовно-культурных ценностей из одной среды в другую, из национальной «окраины», каким являлся Казахстан в досоветский и советский периоды, в «метрополию», каковой, при всех оговорках, была Россия. Н. А. Анастасьев подходил для этого как нельзя лучше, тем более что у него имелся довольно удачный опыт работы над жизнеописаниями иных казахских писателей; его перу принадлежат две книги о выдающихся деятелях Казахстана: о современном прозаике и переводчике А. К. Нурпеисове [Анастасьев, 2004] и классике новой казахской литературы М. О. Ауэзове [Анастасьев, 2006].

Тем не менее многогранность подхода к жизни и творческому наследию Абая, оценка его с высоты «птичьего» полета, в ракурсах разных культур, не должны отменять наличия «периферийных», «второстепенных» деталей, из которых складывается биографическая канва в ее реальном преломлении; систематический труд - по самому определению этого жанра предполагает их учет. Между тем в книге Н. А. Анастасьева встречаются «лакуны», имеется неполнота в изложении биографического сюжета. Об этих досадных «пропусках», собственно, и пойдет речь в основной части настоящей статьи.

\section{2. Методы и материалы}

Методологическую основу исследования в полном соответствии с ее логикой составили два традиционных, выдержавших испытание временем подхода: а) биографический и б) историко-культурный.

Первый метод, как известно, является ведущим в гуманитарных науках. Его специфика в данном случае определяется связью личности писателя и его творчества. Факты жизни оказывают воздействие на человека, формируют его духовно-нравственный опыт, создают условия для реализации дремлющих в глубине души и ждущих часа своего проявления возможностей. 
Художник слова в равной мере - как обладатель индивидуальных представлений и склонностей, так и носитель образа окружающего мира, той среды, в которой он рос и развивался.

Второй метод, в свою очередь, позволяет понять механизмы становления личности в ракурсе конкретной исторической эпохи и включенных в нее культурных традиций. Здесь производится учет «ближнего» и «дальнего» контекстов памяти и судьбы, уточняется степень их внутренней корреляции, благодаря чему описание жизни получает гораздо большую достоверность.

Краеугольные принципы названных подходов использовались в зависимости от собранного материала и поставленных задач.

\section{3. Результаты}

Одна из «лакун» анастасьевской книги, к примеру, касается малой освещенности темы пребывания Абая в семипалатинском татарском медресе Ахмета Ризы, хотя там в течение нескольких лет, с 1855 по 1858 годы, поэт осваивал каноны мусульманского вероучения и восточные языки. Факт учебы пространно упомянут в начале второй главы «У себя, в юрте»:

Двенадцати лет от роду ${ }^{1}$ мальчик был направлен в семипалатинское медресе имама Ахмета Ризы, где и провел несколько последующих лет, заучивая суры Корана $<\ldots>$, научаясь арабскому и персидскому языкам и впервые прикасаясь к сокровищам классической поэзии Востока, что питала его собственные робкие опыты <..> первоначальных времен [Анастасьев, 2008, с. 23].

Событие учебы также упомянуто в конце книги, где приводится простая датировка основных событий жизни Абая; черно-белая фотография мечети Ахмета Ризы внутри книги не в счет.

Но, кажется, нет сомнений в том, что читателю было бы чрезвычайно любопытно узнать, почему Кунанбай выбрал для сына это учебное заведение, как мог Абай, учась в медресе, недолго посещать русскую приходскую школу, какое вообще значение в становлении Абая имел татарский элемент, заключенный в систе-

\footnotetext{
${ }^{1}$ В старом путеводителе по музейному комплексу Абая в Семипалатинске сказано: «Абай он жасқа толғанда, әкесі оны Семей қаласына әкеліп медресеге оқуга береді. - Когда Абаю исполнилось десять лет, отец привез его в Семипалатинск и отдал в медpece Ахмета Ризы» [Литературно-мемориальный музей Абая, с. 16, 50] (курсив мой. - Р. Б.).
}

ме мусульманского образования. Все эти вопросы Н. А. Анастасьевым обойдены - и не только потому, что в предшествующую советскую эпоху, на которую автор все же прилежно опирается, всячески подчеркивалось русофильское начало творчества Абая, а его ориентальные корни ретушировались, так что сейчас приходится наощупь, методом реконструкции, не имея на руках достаточных архивных материалов, воссоздавать семантическое поле связи поэта с Востоком, но и потому (выскажем предположение), что автор отчего-то не заметил татарского фактора, изучая и затем излагая историю Степного края, того же Семипалатинска, в котором татарское купечество с его финансовым и материальным капиталом занимало далеко не последнее место. Автор, как можно понять, бывал в этом городе и наверняка мог обратить свое внимание на то, что двухэтажный дом-особняк земляка, служащего государственного банка, переводчика и адвоката Анияра Молдабаева, в котором останавливался Абай с 1878 по 1904 годы, медресе с двориком, мечеть - все эти здания расположены в Татарском крае (слободе) современного Семея, уникальном историческом месте города, «музеем под открытым небом», и что даже минарет мечети Ахмета Ризы был построен по обычному для казанско-татарской храмовой архитектуры стилю: путем возведения над крышей дома.

Отметим, что в комплекс Татарского края входят и другие сохранившиеся до сего дня мечети: а) деревянная одноминаретная, возведенная на деньги татарского купца И. Музафарова в 1910 году вместо прежней, обветшавшей; высказываемую нередко версию о том, что она-де была построена «неким казахом», из богоугодных соображений пожелавшим остаться неизвестным, следует отнести к числу легендарных; но это, впрочем, ничуть не исключает посильной помощи в строительстве храма казаховмусульман, торговавших поблизости мясом и мясными изделиями и именовавших весь окружный локус «бас сирақ»ом, буквально «голенью головы»; мечеть тем не менее всегда называлась «татарской» - как по общему архитектурному решению, так и по культурноландшафтной вписанности; б) каменная одноминаретная, созданная в 1908-1910 годах на средства татарского купца второй гильдии Латыфа Садыковича Мусина (в 1890 году его отец построил в городе первую механизированную паровую мельницу по европейской технологии) вместо деревянной, которая была сооружена 
казанскими татарами еще в 1837 году и уничтожена пожаром 13 мая 1902 года; архитектором стал османский мастер (из Стамбула) Абдулла Эфенди, помогал ему прииртышский зодчий-самоучка Баязит Сатбаев (1870-1954); утверждают, что к мечети из рядом расположенного дома Мусиных вел специальный подземный ход, чтобы глава семейства мог спокойно посещать храм и совершать намаз в любую погоду; в) каменная двухминаретная соборная, возведенная в 1856-1862 годах русским архитектором Р. А. Болбатовым (Болотовым) и инженером-поручиком Макашевым по турецким конструктивным образцам на месте дотла сгоревшей деревянной; финансировали это строительство несколько богатых татарских купеческих домов (Абдышева, Нигматуллина, Рафикова, Сулейменова, Халитова); мечеть посещал Абай с отцом; ее цветное изображение и описание попало в альбом о крупных мусульманских храмах Российской империи, выпущенный в 1914 году к 300-летию правления династии Романовых; г) одноминаретная деревянная на левом берегу Иртыша, в Заречной слободке («город Алаш»), построенная усилиями казахского старейшины, купца второй гильдии Тыныбая Каукенова в 1836 году; стиль мечети определяется как сибирско-татарский. Мы указали здесь лишь на четыре мечети, но до революции их было больше (на два берега Иртыша около 17 , по устному сообщению краеведа Шавката Файзуллина; в середине 1850 -х годов, когда в город был переведен солдатом Ф.М. Достоевский, - 7 [Врангель, с. 20]).

Все это и многое другое - яркие свидетельства присутствия и активной культурной деятельности сибирских и волжских татар в Степном регионе, который они осваивали едва ли не с двадцатых годов XVIII века, когда пришли сюда по торговым делам вслед за казачьими отрядами ${ }^{2}$; это была форма мирной интеграции в жизнь Империи после долгого сопротивления, вызванного падением Казанского ханства в 1552 году. Татарский же край, находящийся на правом берегу Иртыша, был образован в конце XVIII века, после сильного наводнения, во время которого часть Полковничьего острова, где до того компактно селились татары, оказалась затопленной, и им пришлось переселиться на

\footnotetext{
${ }^{2}$ Вблизи Семипалатинска было много мелких татарских поселений; так, одно из них - село Акколь, основанное, по документам, в 1812 году, - к началу $\mathrm{XX}$ века включало более 50 домов и мечеть.
}

новую территорию выше района проживания и постепенно обжить ее.

Личность Ахмета Ризы примечательна. Казанский татарин, он был учеником Шигабутдина Марджани, сторонником идей джадидизма (религиозной реформы), которые проникали в Казахскую степь, начиная с середины XIX века. Обучение в новометодном медресе проходило интенсивнее в сравнении с медресе старого типа; за два-три года в нем можно было пройти программу, на которую в кадимистском учебном заведении уходило не менее десяти лет. В медресе поощрялось увлечение светскими науками, учащиеся не чурались русской культуры и языка, а мударрисы не чинили препятствий талантливым ученикам в одновременном посещении русской школы, чем Абай не преминул воспользоваться (когда-то неверно писали, что он изучал русский язык «вопреки всем правилам духовной школы» [Ахметов, с. 61]). В медресе Ахмета Ризы Абай начал писать первые стихи на средневековом книжном чагатайском наречии, подражая суфийским поэтам, у которых он по традиции просил духовного снисхождения-покровительства. Есть основания думать, что учителя медресе развивали в Абае эту грань сознания и деятельности, видя в ней проявление глубокого творческого дарования, ведь схоластический подход в преподавании дисциплин джадидами старательно исключался. Вероятно, Абай мог получить много больше, если бы продолжил обучение. Отцу он был необходим в практических целях, как административный помощник в волостных делах, наполненных бесконечными в Степи спорами, тяжбами и пересудами, о которых с неподдельной печалью, будучи человеком почтенного возраста, с опытом большой и многотрудной жизни, его сын скажет в «Первом слове» («Бірінші сөз»), своеобразном вступлении, «Слов назиданий» / «Книги слов» («Қара сөз»):

Бұл жасқа келгенше жақсы өткіздік пе, жаман өткіздік пе, әйтеуір бірталай өмірімізді өткіздік: алыстық, жұлыстық, айтыстық, тартыстық әурешілікті көре-көре келдік. Енді жер ортасы жасқа келдік; қажыдық, жалықтық; қылып жүрген ісіміздің бәрінің баянсызын, байлаусызын көрдік, бәре қоршылық екенің білдік. - Хорошо я жил или плохо, а пройдено немало: в борьбе и ссорах, судах и споpax, страданиях и тревогах дошел до преклонных лет, выбившись из сил, пресытившись всем, обнаружил бренность и бесплодность своих деяний, убедился в унизительности своего бытия [Абай, с. 66, $186]$. 
Однако и того, что Абаю было передано в медресе, хватило с лихвой, чтобы спустя много лет, в зрелый период жизни, развить до необычайной высоты. Новометодное образование и было ответом на догматический «магометанский пуританизм», который с прорусских просветительских позиций осуждался Ч. Ч. Валихановым в статье «О мусульманстве в Степи» (1863-1864). Он призывал российское правительство ограничить татарское религиозное влияние на казахов, осмысливая его как пагубное, фанатичное, бесплодное. «Под влиянием татарских мулл, среднеазиатских ишанов $<\ldots>$, - писал он, - народность наша $<\ldots>$ принимает общемусульманский тип <...>. Мы должны обойти татарский период $<\ldots>$, со времени присоединения Казани и Астрахани $<\ldots>[\text { они }]^{3}$ не дали своему отечеству хоть сколько-нибудь известного деятеля <..> надо принять меры, чтобы $<\ldots>$ остановить дальнейшее развитие ислама $\langle\ldots>$, устранить вредное влияние татарских мулл <...> [Валиханов, с. 293-294]. Подобная позиция, если оставить в стороне значительно более общий контекст (желание имперского правительства оградить казахов от «экономической и культурной экспансии татар» [Мусабалина, с. 25], ослабить административными мерами «конкурентоспособность татар в Степи» [Гибадуллина, 2015, с. 124]), могла сформироваться потому, что к середине XIX столетия ислам, все его учебнообразовательные учреждения испытывали серьезный кризис, который и преодолевался джадидскими реформами. Об устарелости, косности, консервативности обучающих подходов в медресе откровенно писал и Абай в «Тридцать восьмом слове» («Отыз сегізінші сөз»):

Бұл күндегі тәхсилғұлүм ескі медреселер гұрпында болып, бұл заманға пайдасы жоқ болады. - В наши дни методы обучения в медресе безнадежно устарели, оказались не только бесполезными, но и вредными ${ }^{4}$ [Абай, с. 125, 243].

Учтем, ко всему прочему, и то, что основам арабо-тюркской грамоты до поступления мальчика в медресе Абая обучал татарин мулла Габитхан, о чем у Н. А. Анастасьева нет ни слова, хотя М. О. Ауэзов, указав на этническую при-

\footnotetext{
${ }^{3}$ Татары.

${ }^{4}$ Перевод К. Серикбаевой не совсем точно отражает исходную абаевскую мысль, у Абая буквально так: «Практикующиеся и поныне в cmapblx медресе формы обучения для нашего времени бесполезны» (курсив мой. - Р. Б.).
}

надлежность священнослужителя («Құнанбай қолында Ғабитхан сияқты татардан < ..> болушы еді. $-<\ldots>$ при нем находились татарин мулла Габитхан... <и др. - Р. Б.>»; «оказахившимся татарином» Габитхана определила Н. Д. Нуртазина [Нуртазина]), вывел его в качестве персонажа на страницах романа «Путь Абая» («Абай жолы»), причем в лестном свете увлеченного книгочея:

Ғабитхан да кітап оқығыш болатын. Соның кітаптарының ішінең өзін қызықтырған көп-көп асыл бұйымдар тапты. Мұнда Абұлқасым ТусиФирдоуси, Низами, Физули, Науаи, Бабырлар бар. «Жәмшид», «Сеидбаттал Ғази», «Мың бір кеш», «Табары жазған тарих», «Жүсіп-Зылиқалар», «Ләйлі-Мәжнүндер», «Көрұғлы» сияқты хикая дастандар да бар. Абайдың бас алмай оқығандары осылар [Әуезов, с. 134]. - Мулла Габитхан был большим любителем книг. В его собрании Абай нашел произведения Фирдоуси и Низами, Физули и Навои, «Жамшид» и «Тысяча и одна ночь», «История» Табари, «Жусуп и Зулейха», «Лейли и Межнун», «Кер-оглы». Абай читал их не отрываясь [Ауэзов, с. 146].

\section{4. Обсуждение}

Другая «лакуна» связана с тем, что автор не посвятил ни одной строки фактам посещения юным Абаем дома татарского купца второй гильдии Халиуллы Бекметова в Каркаралинске, хотя они, столь знаменательные не только в житейском отношении, лаконично упоминаются в ауэзовском романе:

Абай әкесімен бірге Қарқаралыда тұрғалы көп күндер болды. Қазірде кыс әбден түсіп, қар бекіп алған-ды. Құнанбай кішкене қаланың тап ортасындағы көк шатырлы, үлкен ағаш үйді жатақ еткен. Қазағуар, қонақшыл, татар саудагерінің үйі [Әуезов, с. 96]. - Абай с отцом давно уже приехали в Каркаралинск. Стояла зима, снег плотно укутал землю. Кунанбай поселился в центре этого небольшого города, в просторном деревянном доме с зеленой <буквально «синей», казах. «көк». - Р. Б.> железной крышей. Дом принадлежал гостеприимному татарину-торговцу, любившему общество казахов [Ауэзов, с. 112].

М. О. Ауэзов не назвал (не пожелал назвать?) «гостеприимного татарина» по имени, но краеведы Каркаралинска и биографы Абая хорошо знают, что речь тут идет либо о Хамите Бекметове, либо о его сыне Халиулле, друге и родственнике Кунанбая Ускенбаева. Попробуем объединить некоторые разрозненные сведения о них. 
Род Бекметовых, если полагаться на «документированную» в Казахстане часть истории (неполную родословную, шежере), имеющуюся в нашем распоряжении, ведет происхождение от некоего Бек Бау (по другой шежере - Оке), который жил, судя по всему, в середине XVII века на землях бывшего Казанского ханства. Фамилия «Бекметов» (с русским суффиксом ов, но есть и иные варианты написания: «Бекметев», «Бекметьев»; форма «Бекметев» в источниках на русском языке встречается, по крайней мере, с начала - середины XVIII столетия; в арабском написании возможны разночтения из-за отсутствия конечной огласовки: (بيكميذّ) образована от слова «Бекмет» ${ }^{5}$, которое, в свою очередь, является редуцированной формой имени «Мухаммад» («Ахмед», «Хамед», «Махмуд») с добавлением лексемы «бек» («бәк») - наследственного титула тюркской родоплеменной и феодальной знати. Полная форма была постепенно утрачена, распространение получила сокращенная, в которой лексема «бек» не воспринималась в качестве элемента, указывающего на социальный статус человека, произошло ее слияние с именем; ср.: Амир / Амирхан, Султан / Султанбек.

В татаро-башкирском регионе (бассейн рек Мензеля и Ика) существовали села, связанные с именем «Бекмет»: «Бекмет» / «Бекметово», «Драгун Бекмет», «Старый Бекмет», «Новый Бекмет», «Сарайлы Бекмет»; их основали казанские татары, продвигавшиеся к Уралу, чем вызывали недовольство местных башкир: показательно обращение в Уфимскую провинциальную канцелярию 31 декабря 1759 года башкирских старейшин, они жаловались на то, что татары и «мишары» заселяют их земли «без оброка и насильством», в тексте упоминаются и «ясачные» татары Бекметевы - Якуп, Уразай и Муса - живущие «самовольством» [Амирханов, c. 164-165]. Среди башкир фамилия «Бекметов» тоже встречается. Так, Давлетша Бекметов, сын юртового старшины деревни Курма-

\footnotetext{
5 Созвучная русская дворянская фамилия «Бекетов(ы)», по версии Н. А. Баскакова, имеет основой слово «бекетка», так называли вплоть до начала XX века в Бухарском эмирате, Хивинском и Кокандском ханствах «воспитателей ханского сына» (придворное звание); примыкает к такой версии происхождение фамилии «Бекетов(ы)» от арабского имени существительного в кыпчакизированной адаптации «бәхет» («счастье») и тюркского глагольного императива «бек ет» («укреплять», «делать крепким») [Баскаков, с. 161-162].
}

ново Пермской губернии Саид-Ягъфара, - личность известная. В 1831 году он ездил в Петербург, получив разрешение на аудиенцию с Николаем I: решался болезненный для башкир вопрос о вотчинном владении земель.

После падения Казани и последовавшими за этим попытками христианизации края часть представителей рода отправилась на юговосток, в Оренбургское пограничье, где с течением времени обосновалась в Сеитовой слободе (Татарской Каргале), созданной в середине XVIII века в качестве центра транзитной торговли между Россией и Средней Азией, а также Индией и Китаем ${ }^{6}$, или, во всяком случае, находилась в сотрудничестве с сеитовскими купцами, нанимаясь в караванные выезды.

Начиная с 30-40-х годов XVIII века, Бекметовы входили в разряд толмачей, к посредническим услугам которых прибегало Российское государство в его сношениях с обширной Казахской степью. Так, к названному периоду относится переводческая деятельность Арыслана Бекметева (в российских документах - «Араслан»; его отношение к казахской ветви рода есть вероятность простого однофамильства! устанавливается по косвенным данным и нуждается в тщательном изучении). Это имя фигурирует в материалах по истории Башкортостана и казахско-русских связей [Султангалиева]. Начав свой путь в Уфимской провинциальной канцелярии в 20-х годах XVIII века (его имя и фамилия значатся в материалах ландратской переписи 1716-1717 годов как сотника Арской дороги Казанского уезда [Материалы ландратской переписи, с. 260-261]), он служил переводчиком в Оренбургской пограничной комиссии. Переводил письма Абулхаир хана (хана Младшего Жуза, или «Меньшой Киргизской Орды», как писалось в русских источниках) к императрице Анне Иоанновне, персидскому шаху Надиру, хану Хивы [Султангалиева, с. 132] (см. переводы Арыслана Бекметова с татарского: [Поездка из Орска в Хиву..., с. 19-29], его подпись в земельных актах башкирских племен: «при письме той записи толмачил Араслан Бекметев и татарским письмом руку приложил», здесь он - переводчик Комиссии баш-

\footnotetext{
${ }^{6}$ Сеитова слобода (посад) была образована усилиями казанско-татарских купцов (прежде всего Сагита Хаялина, который обратился к властям Оренбургской губернии с соответствующей просьбой), желавших освободиться от рекрутской повинности и свободно исповедовать веру отцов, занимаясь торговыми делами.
} 
кирских дел, см.: [История башкирских родов..., с. 126-127]); участвовал в сложных переговорах оренбургских губернских властей с Абулхаир ханом; готовил донесение о взаимоотношениях башкирских и казахских племен (что предполагало долю политической разведки); уйдя в отставку, поселился в Сеитовой слободе и стал хозяином большого двора с 4 мельницами и прислугой в 25 душ обоего пола. Все это было завещано трем сыновьям, один из которых, Усман Арысланов («Арасланов»), также служил в качестве толмача Оренбургской комиссии. В 1740-1741 годах он сопровождал поручика Оренбургского драгунского полка Дмитрия Гладышева во время его поездки в Хиву через кочевья Абулхаир хана, о чем имеется запись в «Материалах поездки поручика Оренбургского драгунского полка Дмитрия Гладышева и геодезиста Ивана Муравина из Оренбурга в Хиву к хану Абулхаиру (5 ноября 1740 г. - апрель 1741 г.)». Симптоматично, что в современном научном издании этого текста персоналия Усмана Арысланова не прокомментирована, не «распознана» [Путевые дневники...]. Как и отец, он переводил официальные русские письма, адресованные шаху Надиру, более того - доставлял их в Персию. Любопытен следующий факт его жизни. В 1746-1747 годах Усман попал в плен к Абулхаиру, став заложником переменчивых отношений, которые сложились между казахским ханом и оренбургским губернатором И. И. Неплюевым. В Казани (по иной трактовке - в Оренбурге [Там же], а скорее, попеременно в этих городах с 1738 по 1748 годы) находился султан Кожахмет, сын Абулхаира; российское правительство держало его при себе для «сговорчивости» хана. Обмен был произведен, и в 1750-е годы Усман Арысланов переводил официальную переписку Нуралы, нового хана Младшего Жуза после гибели Абулхаира, его отца (в пояснениях к «Материалам...» сведений о «технической» стороне обмена нет). Это отнюдь не случайно: должности толмачей на пограничной зоне тогда по сословно-табельному принципу «занимали < ..> представители титулованной татарской знати <она зарекомендовала себя с лучшей стороны в более ранний период так называемых “служилых татар”, выходцев из Золотой Орды. - Р. Б.>» [Султангалиева, c. 127]. Их отбор производился по результатам строгой и всесторонней проверки; учитывались как деловые качества, так и государственнополитическая благонадежность [История татар, c. 339] (последнее порой приводило к недоверию со стороны коренного населения).

Что касается казахской ветки рода Бекметовых, то она восходит к началу 30 -х годов XIX века, когда в Каркаралинский край из деревни По Ключу Сап (тат. Сап-баш / Саф(лы) баш) Шиньшинской волости Царевококшайского округа Казанской губернии [Мустафин, 2000, с. 5], [Мустафин, 2020] ${ }^{7}$ приехали два брата - Хамит и Джагфар Бекметовы. Живописный озерно-холмисто-лесостепной оазис Сары Арки (Центрально-Казахстанский мелкосопочник, «казахское Макондо», как поэтично охарактеризовал его один из нынешних путешественников и блогеров) им понравился, дела быстро пошли в гору, братья, сначала приписанные к Петропавловску [Кретова, с. 158], стали богатеть (особенно - после открытия в 1848 году Кояндинской ярмарки, центра торговли в Степи азиатскими и европейскими изделиями, и возможности бывать на приграничной полосе с Синьцзянем [Гибадуллина, 2016, с. 34], см.: [Гибадуллина, 2017]), и Хамит в Каркаралинске построил просторный двухэтажный бревенчатый дом, без единого гвоздя, с уникальными голландскими печками в каждой комнате, в котором бывал Кунанбай, будучи ага-султаном (старшим султаном с 1849 по 1853 годы) Каркаралинского внешнего округа. Когда по инициативе Кунанбая и в результате его обращений в высшие инстанции российской власти в 1851 году в Каркаралинске была построена первая мечеть (сейчас одна из старейших в Казахстане, сакральный памятник, охраняемый государством), празднование («той») этого события после коллективного намаза происходило в доме Хамита и Халиуллы [Мустафин, 2020], том самом - с «зеленой крышей» («бекметевский дом под синей крышей»); одним из тех, кто оплачивал возведение храма, был Халиулла [Нурмаханов]; локус для строительства выбирал Кунанбай, но имеются сведения, со-

\footnotetext{
${ }^{7}$ Ныне село Ключи-Сап в Атнинском районе Республики Татарстан, бассейн реки Шор, в 30 км. к северу от села Большая Атня (Олы Әтнә), на границе с Республикой Марий Эл. Основано во второй половине XVIII века. На 2002 год насчитывало примерно 300 человек жителей. Знаменательно, что по состоянию на начало XX века (1907 год) в нем, согласно данным Оценочно-статистического бюро Казанского губернского земства, жило 732 человека обоего пола, все татары, несмотря на рядом расположенные русские и черемисские деревни [Список селений..., c. 27].
} 
гласно которым он утвердил предложение Хамита о местоположении возводимой мечети; при ее постройке привлекалась рота солдат Каркаралинской крепости - по договору, за определенное вознаграждение, «в свободное от службы время», как было подчеркнуто в резолюции начальника Сибирского пограничного управления генерал-майора Н. Вишневского [Нурмаханов, с. 106], [Жетписпаева]. В романе М. О. Ауэзова дается описание торжественного послемолитвенного застолья:

Қора ішінді күтушілер, аспазшылар болмаса, өзге жүргіншілер жоқ <..>. Үлкен ағаш үйдің қораға шығатың кең есігіне қарсы кішілеу ас үй бар еді. Соның есігі дамыл таппай ашылып-жабылып жатыр екен. Табақ-табақ ыстық асты <...> жігітітер жүгіре басып тасып жүр. Осы кіре беріс бөлмеден төрге қарай және оң жақ, сол жаққа қарай бірнеше бөлме бар еді. Дәл оң жақтағысы Құнанбай жататын үлкен бөлме. Сол үй жақтан зор дауспен көңілдене сөйлер отырған Алшынбай, Майыр үндері келеді. Тұтасқан қатты күлкі де естіліп қояды <...> Төрдегі бөлмелер екеу еді. Онда да жағалай тізіліп, малдас құрып, сығылыса отырған қонақтар екен. Бұндағы қонақтың көбі қаланың татар саудагерлері, қазақ байлары <..> көрінді [Әуезов, с. 199-121]. - Во дворе, полном оседланными лошадьми, не было никого, кроме слуг и людей, занятых стряпней <..>. Прямо против крыльца большого деревянного дома помещалась отдельная кухня. Дверь ее то и дело хлопала. Жигиты <..> один за другим выносили блюда с горячим, дымящимся мясом <..>. Направо была большая комната, где сидел Кунанбай. Оттуда доносился громкий, оживленный разговор <..>. Комната напротив входа тоже была битком набита гостями, сидящими тесным кругом. Это преимущественно городские купцы - татары, казахские баи [Ауэзов, с. 133-134].

Мечеть сочетала казахские и татарские архитектурно-декоративные элементы. Первым имамом мечети, по приглашению Кунанбая, стал ахун Хасан Сейфуллин, «казанский татарин» по архивным записям, мещеряк родом из Саратова; он умер в 1881 году в Джидде в период чумы, совершая хадж (дочь ахуна Магзума была женой Губайдуллы, сына Джагфара Бекметова, у них было семь детей; Губайдулла являлся имамом мечети после смерти Хасана).

Отцом Хамита и Джагфара Бекметовых был Яхья (в русских казенных бумагах они оба по отчеству - «Яхнины»). Хамит родился по одним данным в 1808 году [Мустафин, 2020], по другим - в 1811 году [Өмірдің бел-белестері, с. 195]. От четырех жен у него было 20 детей (их имена зафиксированы в специальной «Выписке из последнего списка членов семейства умершего купца Хамита Бекметева», составленной в каркаралинской окружной канцелярии); у его младшего брата - трое.

Халиулла был первенцем Хамита: в «Выписке...» он старше всех. Данные о его рождении разнятся: либо 1829 год, либо 1833 год, а дата смерти - 6 мая 1905 года (о годе смерти его отца ничего не известно; предполагают, что Хамит вернулся на родину). Его матерью была Сахипджамал, которую полагают казашкой (возможно, и не вполне чистокровной). Помимо Халиуллы у нее было двое сыновей: Хамидулла и Гиззатулла. Один из сыновей Хамидуллы, то есть внук Хамита и племянник Халиуллы, Мухаммед-Максуд Бекметов (1883-1912), друг А. Б. Байтурсунова и А. Н. Букейханова, видных представителей казахской интеллигенции, был работником Омской телеграфно-почтовой конторы, участвовал во всеобщей забастовке российских почтовых служащих 1906 года, собирал казахский национальный фольклор (см. о нем: [Абдрашитов, Узбаханов], см. составленную им и изданную в Казани антологию казахских стихотворений (степных напевов): [Бекметев]).

Халиулла не только торговал, как и его отец (мукой, хлебом, бакалейными товарами, мануфактурой и др.), но также занимался благотворительностью. Являясь общественным председателем Каркаралинского отделения попечительства о тюрьмах, он жертвовал деньги на улучшение жизни арестантов, в связи чем военный губернатор Семипалатинской области дважды, в приказах от 23 апреля 1885 года и 15 сентября 1892 года, выражал ему «искреннюю и сердечную благодарность». Более того, 12 октября 1888 года император Александр III наградил купца нагрудной серебряной медалью с надписью «За усердие» на Станиславской ленте, а в декабре 1904 года царь Николай II вручил ему золотую медаль «За усердие» на Аннинской ленте для ношения на шее [Жамулдинов, с. 42-43], [Попов, с. 6]. В Каркаралинске были распространены подписные листы с целью сбора средств в помощь сиротам, старикам, военным инвалидам, простым людям, оказавшимся без материальной поддержки (часто после пожаров, когда выгорали целые кварталы с деревянными постройками). Халиулла, его родственники всегда вносили значительные суммы в эти листы; так, сохранился подписной лист за 1911 год на сумму 72 руб. 15 коп.: среди подписавшихся - Махмуд и 
Максут Бекметовы [Попов, Рязанцев, с. 107]. Халиулла был в числе тех меценатов, кто финансировал и строительство Петербургской соборной мечети (его имя в виде арабской надписи отмечено на одной из стен храма) [Керейбаева, с. 145]. В 1905 году вместе с другими, по преимуществу русскими, купцами Халиулла входил в состав Каркаралинского общества народной трезвости 8 .

${ }^{8}$ Вся эта деятельность не мешала иногда «сорить» деньгами! Старожилы Каркарлинска в советские времена рассказывали, что купцы Бекметовы имелиде обыкновение топить самовары бумажными ассигнациями. Это касалось, например, сватовства дочерей для определения размера кошельков будущих избранников, а заодно и для уточнения степени их деловитости, пригодности к жизни, серьезности отношения к выбору возлюбленной. Такого рода шутливыми историями забавлялись, конечно, для «красного словца», особенно когда Каркаралинск посещали приезжие, туристы, интересовавшиеся местными нравами. Но как не бывает дыма без огня, так не могут многочисленные и веселые рассказы о купцах распространяться без конкретных событий, зафиксированных почти «документально». Дело в том, что сжигание денежных купюр для нагрева самовара - сюжет едва ли не инвариантный, он настойчиво повторяется в разных версиях. Это не просто анекдот «с бородой» советского происхождения, вызванный желанием контрастно показать, как люди жили раньше, до революции, и как они живут теперь, при новой власти, - «небо и земля». Нет, история о деньгах и самоваре бытовала в XIX веке, когда Бекметовы и купцы Рязанцовы на Куяндинской ярмарке в пылу торговой конкуренции поспорили о том, кому из них удастся быстрее вскипятить вечерний самовар деньгами. Говорилось, как правило, о том, что победили татарские купцы: им пришлось пустить в оборот живые средства, предназначенные для приобретения угольной шахты, которая наутро после горячих «прений» ушла в руки более предприимчивых и менее авантюрных англичан. Не исключено, кроме того, что в окружении Ф.М. Достоевского, который находился в семипалатинской ссылке (служил рядовым солдатом Сибирского линейного батальона), этот или схожий факт мог быть предметом застольных «пересудов», смешным аргументом в пользу странных обычаев степной стороны - далекой имперской периферии. Вспоминается эпизод ночного кутежа, изображенный в романе «Идиот»: Настасья Филипповна берет у купца Рогожина в своей петербургской квартире деньги и бросает их в печь, ставя условие, что, если кому-то удастся достать из огня хотя бы пачку, тот получит все сто тысяч. В любом случае описанный факт с самоваром нуждается в подробном историкокультурном освещении, начиная с вопроса, было это
Халиулла и члены его семьи владели горными рудниками, Степной край был богат на них. По имперскому закону добыча руды на одном месте осуществлялась в течение трех лет, после чего рудник объявлялся свободным, и его временному хозяину для продления работ надо было высылать новую заявку в Томский горный округ. «Сибирский торговопромышленный календарь», издаваемый в Томске, публиковал список лиц, имевших лицензию на разработку рудников. По подсчетам Ю. Г. Попова, всего от бекметовского семейства в разное время было подано около 100 заявок (!) [Попов, с. 6]. Многие рудники Прибалхашья обозначались по именам членов дома Бекметовых: Асатовский, ХакимМаксутовский, Мугиновский, МахмудМухтаровский, Дильдановский, Хамитовский, Гульшадский (в честь племянницы Халиуллы, Гульшад - дочь его брата Хамидуллы; о геологии этого рудника в начале 1950 -х годов писали: «В Гульшаде миметезит <редкий минерал из класса фосфатов. - Р. Б.> наиболее обычен на участке Бекметевских разносов... Скородит $<$ ядовитый минерал для извлечения мышьяка. P. Б.> в степной части Казахстана в существенных количествах обнаружен только в месторождении Гульшат...» [Чухров, с. 145]; вблизи этой рудной копи в 1885 году был построен завод, на котором опытным методом в отражательных печах извлекалось серебро, см. [Пазухин, с. 42]); Попово-Бекметовским назывался металлургический завод на берегу озера Балхаш (совместный с купцом Степаном Поповым).

У Халиуллы было четыре жены: 1) Латифа, дочь Исхака, 2) Хадича, дочь Рафика, 3) Фатима, дочь Мусы, 4) Гайни (1846-1927). От первых двух жен детей не было; третья родила троих (одну дочь и двух сыновей); четвертая пятерых (одну дочь и четырех сыновей). Последняя жена Гайни (или, как ласково называли ее казахи, Айнеке) являлась дочерью Шонбая из рода тобыкты, близкого родственника Кунанбая. Она рано овдовела (ее муж Смаил $<$ Исмагил. - P. Б.> погиб, упав с лошади), от первого брака у нее осталось двое маленьких детей [Бекметьева, с. 125]. Кунанбай, посещавший дом Хамита, предложил Халиулле взять молодую Гайни в жены и усыновить ее детей. Тот согласился - не только из желания породниться с Кунанбаем, но и потому, что от трех

на самом деле или нет, и заканчивая проблемой семиотики купеческих жестов и поступков. 
первых жен у него к моменту очередного сватовства детей не было. Когда же Гайни пришла в дом, узбечка Фатима, о которой думали, что она бесплодна, стала рожать... С образом Гайни был связан культ детей и детства. По воспоминаниям современников, внешне суровая, в душе она была добрейшим человеком. Судьба детей Гайни от Смаила была трагической: Жакыпбек стал жертвой политических репрессий 1930-х годов, Рабига умерла в безвестности в 1951 году9. В то же время другие дети Халиуллы, в том числе от Гайни, внесли большой вклад в развитие казахской - да и русской! культуры (от двух жен было восемь детей: от Фатимы - одна дочь и два сына, от Гайни - четыре сына и одна дочь). Все они, их родственники и потомки получили хорошее образование и воспитание: достаточно сказать, что дочь Халиуллы от Фатимы Гульбахор вышла замуж за Жакыпа Акпаева (1876-1934), первого казахского магистра права, окончившего юридический факультет Императорского СанктПетербургского университета, этнографа, общественного деятеля, члена правительства «Алаш-Орда», которое ратовало за европейский, западный путь развития нации и было упразднено большевиками; Махфуза (188?-1956), дочь Губайдуллы Бекметова, двоюродного брата Халиуллы, состояла в законном браке с Амре Айтбакиным (1861-1919), первым казахским профессиональным врачом, деятелем политической партии «Алаш» (см. о нем: [Фоминых, Кузьмин, Некрылов]), его сестра была женой племянника Зейнеп Чормановой, матери Чокана Валиханова; внучка Халиуллы, дочь его сына Мажита, Гульгасыл была замужем за Анатолием Степановичем Ивановым (1928-1999), автором популярных романов «Тени исчезают в полдень» и «Вечный зов», повести «Ермак», редактором журнала «Молодая гвардия» (Гульгасыл Мажитовна Бекметова для своего мужа почти то же, что Софья Андреевна Берс для

\footnotetext{
${ }^{9}$ У Хамита от Хусни (Хусниджамал), второй - после Сахипджамал - жены, был сын Хакимжан. Он приходился Халиулле сводным братом, жил в его семье, будучи как бы «усыновленным», «приемным», по возрасту подходил: все из-за долгого отсутствия у Халиуллы собственных детей. Хакимжан, любимец Халиуллы (до наших дней дошла черно-белая фотография, на которой они оба запечатлены: «братотец» трогательно держит «брата-сына» за плечо), погиб по окончании Сибирского кадетского корпуса в Омске, лучшего военного учебного заведения в дореволюционной России.
}

Льва Николаевича Толстого: не случайно текст романа «Тени исчезают в полдень» посвящался жене - «Галине Ивановой, верному другу» ${ }^{10}$ ).

Халиулла по делам посещал Петербург. Естественно, оттуда он привозил книги на русском языке, которые пополняли его домашнюю библиотеку, представленную арабскими, персидскими и тюрко-татарскими изданиями. Можно предположить, что ею пользовался и любознательный Абай. В доме Бекметовых звучала музыка: кто-то из молодых играл на инструменте (скрипка, гармонь), а родители поддерживали детей в их талантах (кстати, детям в семье было принято давать «внутренние», домашние имена). Культурный контекст в итоге не мог не оказать влияния на юного Абая; он дышал воздухом знаний и свободы щедрого бекметовского дома.

10 Характерны высказывания Д. Л. Быкова о месте
прозы А. С. Иванова в советской и постсоветской
литературе. Их стоит привести. Отдавая должное
таланту писателя («у Иванова был несомненный дар
романиста»), Д. Л. Быков аттестовал его в качестве
«гения для бедных» и подчеркнул, что это вовсе не
плохо («препарирование высоких образцов для ус-
редненного читателя - задача вполне благородная»). Летописью эпохи, с его точки зрения, были не только романы М. А. Шолохова, но и произведения А. С. Иванова. Как вывод: «Когда мы начнем <..> выстраивать нормальную национальную идентичность $<\ldots>,-$ нам придется перечитать и его $<$ А. С. Иванова. - P. Б.> прозу. Адаптация великих образцов для неподготовленного читателя, $<\ldots>$, снабжение его информацией об истории и современности - одна из задач литературы. <..>. И те, кто вырос на $<\ldots>$ Иванове $-<\ldots>$ обеспечили стране запас прочности, благодаря которому она не развалилась после очередной революции. <..> Если бы сегодня нашелся человек, который не побоялся бы стать гением для бедных, - в стране стало бы ощутимо меньше бедных <бедных интеллектуально, духовно, морально. - Р. Б.>» [Быков, с. 411-412]. Отметим, что до сих пор тиражи сочинений А. С. Иванова высокие, а читательские отзывы о нем даже в Интернете - неизменно положительные; в них отражается не только ностальгия по ушедшей эпохе, но и чувство того, каким должна быть подлинная массовая литература: легкая в чтении, глубокая по мысли, оставляющая тонкое приятное эстетическое «послевкусие». Многие пишут о том, что писатель остался недооцененным, и это справедливо: нет его биографии в «Жизни замечательных людей»! Постоянное воодушевление вызывают и советские киносериалы, снятые по романам А. С. Иванова (оригинальный авторский сценарий, актерская игра, музыкальное оформление, цветовое решение, антураж, сибирская природа). 
Халиуллу Хамитовича Бекметова похоронили на родовой части каркаралинского кладбища. Камень на его могилу был привезен из Индии, железную ограду сделал местный мастер-умелец, кузнец Кынабай [Мустафин, 2016].

\section{5. Выводы}

О факте теплых встреч Кунанбая с Бекметовыми можно было бы упомянуть в книге кратко, в сжатых констатирующих формулировках, без ухода от основной траектории повествования. Справедливости ради следует сказать, что Н. А. Анастасьев оговаривает жанровые границы своего труда. В «Прологе» он пишет, что его книга - не биография, не литературно-критические очерки, а портрет, набросок к нему или - в более лирическом преломлении - «медальон в колеблющемся окружении званых или призванных участников литературнообщественной жизни прежних веков» [Анастасьев, 2008, с. 7]. Оговорка существенная: она соответствует авторской логике в осмыслении творчества Абая (и не только его: любого художника!). Мы не ставим целью ее оспорить или пересмотреть, понимая, что без внутренней духовной близости (Н. А. Анастасьев объясняет, что ее у него нет по объективным причинам) биографию освещать, действительно, трудно. Мы указываем на фон («окружение») ранней социально-культурной жизни Абая, фон, который все-таки лежал на поверхности и в силу слишком обобщенного подхода к теме оказался совершенно не замеченным. Почти аналогичное положение - в книге О. И. Ибраимова об Ч. T. Айтматове, изданной в той же серии «Жизнь замечательных людей» десятью годами позже [Ибраимов]. Правда, о татарской генетике киргизского писателя по материнской линии здесь сказано (сейчас это невозможно обойти молчанием!) - но, увы, скупо, на одной-двух страницах, без привлечения огромного материала о славном купеческом семействе Абдувалиевых.

\section{Литература}

Абай. Қара сөз. Книга слов. Семей: Международный клуб Абая, 2001. 264 с.

Абдрашитов Х., Узбаханов Н. В год великого пробуждения. Алма-Ата: Жалын, 1987. 104 с.

Амирханов Р. Х. Родословная Амирхановых // Татарские мурзы и дворяне: история и современность: материалы Всероссийской научнопрактической конференции, г. Казань, 9 апреля 2010 года. Вып. І. Казань: Изд-во «Фән» АН РТ, 2010. С. 156-247.

Анастасьев Н. А. Абай: тяжесть полета. М.: Молодая гвардия, Астана: Фолиант, 2008. 383 с.
Анастасьев H. A. Мухтар Ауэзов: трагедия триумфатора. М.: Молодая гвардия, 2006. 449 с.

Анастасьев Н. А. «Небо в чашечке цветка»: Абдижамил Нурпеисов и его книги в мировом литературном пейзаже. Алматы: Олке, 2004. 303 с.

Ауэзов М. Путь Абая: роман-эпопея в 2 томах / пер. с казах. Т. I. М.: Художественная литература, $1971.715 \mathrm{c}$.

Ахметов 3. А. Пушкин и Абай // Вестник Ленинградского университета. 1949. № 6. С. 60-70.

Баскаков Н. А. Русские фамилии тюркского происхождения. М.: Наука, Главная редакция восточной литературы, 1979. 280 с.

Бекметьева Ж. О доме с зеленой крышей // Простор. 2000. № 12. С. 123-130.

Быков Д. Л. Советская литература: краткий курс. М.: ПРОЗАиК, 2013. $416 \mathrm{c}$.

Валиханов Ч. Избранные произведения. М.: Наука, Главная редакция восточной литературы, $1986.414 \mathrm{c}$.

Врангель A. E. Воспоминания о Ф.М. Достоевском в Сибири 1854-1856 гг. СПб.: Типография А. С. Суворина. 1812. 221 с.

Гибадуллина Э. М. Участие татар в периодическое торговли Казахстана. XVIII - начало ХХ вв. Казань: РИЦ «Школа», 2017. 384 с.

Гибадуллина Э. М. Татары Семипалатинска в торговле с Китаем во II половине XIX - начале XX веков // Новейшие достижения в науке и образовании: сборник научных трудов по материалам Международной конференции, г. Смоленск, 31 августа 2016 года. Смоленск: ООО «Новаленско», 2016. С. 32-34.

Гибадуллина Э. М. Правовые аспекты участия татар в торгово-промышленной деятельности на территории Казахстана во II половине XIX - начале $\mathrm{XX}$ веков // Духовная жизнь российских региональных сообществ: история, традиции, современность: сборник статей IV Международной научной конференции, г. Казань, 20-21 октября 2015 года. Казань: Изд-во КГАСУ, 2015. С. 122-126.

Жамулдинов В. Н. Становление и развитие в Казахстане института общественого воздействия на осужденных, его современное состояние и перспективы // Вестник Пермского института ФСИН России. 2013. № 1(8). С. 39-45.

Жетписпаева A. Сквозь века и забвение // Индустриальная Караганда. 2020. 13 июня. URL: http://www.inkaraganda.kz/articles/158066 (дата обращения: 08.01.2021).

Ибраимов О. И. Чингиз Айтматов. М.: Молодая гвардия, 2018. $221 \mathrm{c.}$

История башкирских родов. Еней. Т. І. Уфа: Уфимский полиграфкомбинат, 2014. 432 с.

История татар: в 7 томах. T. VI. Казань: Изд-во AH PT, 2013. $1172 \mathrm{c}$.

Керейбаева $A$. C. Благотворительная и меценатская деятельность предпринимателей Степного края II половины XIX - начала XX веков в контексте российской государственной политики: историогра- 
фический аспект // Казахи Евразии: история и культура. Омск: Изд-во ОмГУ, Павлодар: Изд-во ПГПУ, 2016. С. 143-150.

Кретова T. По сакральным местам Восточного Казахстана // Простор. 2019. № 4. С. 154-164.

Литературно-мемориальный музей Абая: памятка для посетителей / сост. Г. Мухаметханов, М. И. Шаталин. Семипалатинск: Главиздат Министерства культуры КазССР, 1960. 70 с.

Материалы ландратской переписи 1716-1717 годов. Казанский уезд // Родной край (Туган жир). 2018. № 1. C. 256-261.

Мусабалина Г. Т. Общественно-политическая жизнь Восточного Казахстана в XIX веке: исторический анализ: автореф. дис. ... докт. истор. наук. Алматы: Изд-во «Тенгри», 2010. 40 с.

Мустафин E. Каркаралинское окружение Кунанбая // Казахстанская правда. 2020. 24 сентября. URL: https://www.kazpravda.kz/articles/ view/karkaralinskoe-okruzhenie-kunanbaya (дата обращения: 30.12.2020).

Мустафин E. О чем молчат памятники // Казахстанская правда. 2016. 1 октября. URL: http://www.inkaraganda.kz/articles/142555 (дата обращения: 15.01.2021).

Мустафин Е. Татарин, любивший общество казахов // Караганда. 2000. 2 ноября. 10 с.

Нурмаханов A. K. Мечеть Кунанбая Хаджи в Каркаралы (по материалам полевых исследований) // Казахстан в XXI веке: в центре внимания: материалы VI Международной научно-практический интернет-конференции, посвященной выставке «ЕХРО-2017» в Астане. Астана: Изд-во ЕНУ имени Л. Н. Гумилева, 2017. С. 105-108.

Нуртазина Н. Д. Абай и ислам. Alma-mater Ибрагима Кунанбайулы - медресе Ахмет-Риза // URL: https://www.altyn-orda.kz (дата обращения: 20.12.2020).

Пазухин В. A. Металлургия в Киргизской степи. М.; Л.: Промиздат, 1926. 208 с.

Поездка из Орска в Хиву и обратно, совершенная в 1740-1741 годах Гладышевым и Муравиным / изд. с приобщением современной карты
Миллерова пути от Орска до Зюнгорских владений и обратно, Я. В. Ханыковым, действительным членом Императорского Русского географического общества. СПб., 1851.85 с.

Попов Ю. Г., Рязанцев В. П. Корниловы, Карбышевы, Рязанцевы и другие казаки станицы Каркаралинской (штрихи краеведческой летописи). Новосибирск: АРТА, 2012. 142 с.

Попов Ю. Привез купец «огонь священный»... // Казахстанская правда. 2007. 4 августа. 12 с.

Путевые дневники и служебные записки о поездках по южным степям. XVIII-XIX вв. // История Казахстана по русским источникам XVI-XX вв. T. VI. Алматы: Дайк-пресс, 2007. URL: http://www.vostlit.info/Texts/Dokumenty/M.Asien/XVI II/17401760/Muravin_2/text1.htm (дата обращения: 26.12.2020).

Список селений Казанской губернии. Вып. 11. Царевококшайский уезд. Казань: Лито-Типография И.Н. Харитонова, 1913. 43 с.

Султангалиева Г. С. Деятельность татарских переводчиков, толмачей Оренбургской пограничной комиссии в Казахской степи (XVIII-XIX вв.) // Научный Татарстан. 2009. № 4. С. 125-138.

Чухров $Ф$. В. Миметезит и скородит в степной части Казахстана // Труды Минералогического музея. Вып. 3. М.: Изд-во АН СССР, 1951. С. 144-146.

Фоминых С. Ф., Кузьмин А. Н., Некрылов С. А. Амре Айтбакин - воспитанник Императорского Томского университета, первый дипломированный казахский врач // Сибирский журнал клинической и экспериментальной медицины. 2011. Т. 26. № 1. Вып. 1. С. 177-180.

Әуезов М. Абай жолы: роман-эпопея, бірінші кітап. Алматы: Жазушы, 2004. 366 б.

Өмірдің бел-белестері. Перипетии судьбы: посвящается 90-летнему юбилею Беркутбая Айдарханова и 85-летию Халиды Бекметевой. Алматы, 2008. 249 c.

Бекметев М.-M. Х. Қазақ өлеңдері: қазақтың жақсы өлеңдердің жыелды. Казан: Матбуга Кәримия, 1908. 18 б.

\title{
АБАЙ, ТАТАРЛАР ҺӘМ СӘУДӘГӘР БЕКМЕТОВЛАР ЙОРТЫ (Н. А. АНАСТАСЬЕВНЫН «АБАЙ: ТЯЖЕСТЬ ПОЛЕТА» КИТАБЫНА БЕРНИЧӘ ИСКӘРМӘ)
}

\author{
Ринат Ферганә улы Бекметов, \\ Казан федераль университеты, \\ Россия, 420008, Казан ш., Кремль ур., 18 нче йорт, \\ bekmetov@list.ru.
}

Мәкалә Абай Кунанбаевның (1845-1904) тәржемәи хәлен өйрәнү мәсьәләсенә, төгәлрәге Россиядә нәшер ителгән китапларда аны бәян итүнең аерым аспектларына багышлана. 2008 нче елда Казахстан Республикасы Мәдәният һәм мәгълүмат министрлыгы заказы белән “Атаклы 
кешеләр тормышы” («Жизнь замечательных людей») сериясендә Абайның тормышын системалы тасвирлаган рус телендә яңа китап - Россиянең танылган Америка белгече Н. А. Анастасьевның “Абай: очыш авырлыгы” («Абай: тяжесть полета». М.: «Молодая гвардия», Астана: «Фолиант», 383 б.) басмасы дөнья күрде. Әлеге китап жәлеп ителгән тарихи-мәдәни материалы, төзелешенең уйлап эшләнүе, әдәби теле ягыннан унай тәэсир калдыра. Шул ук вакытта аның вакыйгалар схемасында, язучының тәржемәи хәлен тасвирлауда башка бушлыклар белән бергә казах әдәбияты классигы тормышының башлангыч чоры белән бәйле сизелерлек «лакуна» (монда мәдәниятнең милли үзенчәлекле элементы. - ред.) бар. Яшь Абайның әтисе Кунанбай Өскенбаев белән бергә татар сәүдәгәре Хәлиулла Хәмит улы Бекметовның Каркаралыдагы йортында булуы хакында берни дә әйтелми, югыйсә бу турыда автор башка мәсьәләләрдә актив һәм нигезле сылтамалар ясаган М. О. Ауэзовның “Абайның юлы” («Путь Абая») документаль романында языла. Абайның әтисе (Каркаралы волосте солтан-агасы) белән Хәлиулла Бекметов арасында булган тыгыз эшлекле һәм туганлык-гаилә мөнәсәбәтләре факты аерым игътибарга лаек, чөнки ул Абайда китапка һәм мәгърифәтчелек традицияләренә кызыксыну уянуның характеры хакында турыдан-туры булмаган мәгълүматка ия. XIX гасыр - XX йөз башы казах ижтимагый аңын аңлау өчен, гомумән татар мәдәни контекстын исәпкә алырга кирәк.

Төп төшенчәләр: Абай Кунанбаев, Кунанбай Өскенбаев, Семипалатинск, Каркаралы, Казахстандагы татар сәүдәгәрләре, Хәлиулла Бекметов, Бекметовлар йорты. 